\title{
Occurrence of the newly described kinorhynch genus Meristoderes (Cyclorhagida: Echinoderidae) in Korea, with the description of four new species
}

\author{
Martin V. Sørensen - Hyun Soo Rho • \\ Won-Gi Min · Dongsung Kim $\cdot$ Cheon Young Chang
}

Received: 28 March 2012/Revised: 19 July 2012 / Accepted: 23 July 2012 / Published online: 11 August 2012

(C) Springer-Verlag and AWI 2012

\begin{abstract}
Meristoderes is the most recently described kinorhynch genus and has until now only accommodated its type species M. macracanthus from the Mediterranean and $M$. galatheae from the Solomon Islands in Southeast Asia. The present contribution is an account on the genus based on samples from the ongoing exploration of the kinorhynch fauna in coastal and subtidal waters around in the Korean Peninsula. The samples yielded no less than five new species of Meristoderes, of which four are formally described herein, whereas only diagnostic notes are provided for the fifth. The descriptions are supplemented with a key to species of the genus, and morphological notes on the organization of cephalic structures and cuticular trunk structures. New morphological findings include intrageneric variation in the composition of the terminal segment, which may have either one unpaired or two paired tergal plates. The data also show that the differentiation of a tergal and sternal plate in segment 2 varies
\end{abstract}

Communicated by H.-D. Franke.

M. V. Sørensen ( ()

Natural History Museum of Denmark,

University of Copenhagen, Universitetsparken 15,

2100 Copenhagen, Denmark

e-mail: mvsorensen@snm.ku.dk

H. S. Rho - W.-G. Min

Dokdo Research Center, Korea Ocean Research and

Development Institute, Uljin 695-1, Korea

D. Kim

Marine Living Resources Research Department, Korea Ocean

Research and Development Institute, Ansan 425-600, Korea

C. Y. Chang

Department of Biological Sciences, College of Natural Sciences,

Daegu University, Gyeongsan 712-714, Korea greatly between the species. Results of the present study indicate that the genus probably holds a significant, unrecovered biodiversity, but the data also shed light on potential future taxonomic problems among genera of Echinoderidae and stress the importance of identifying additional diagnostic traits to define Meristoderes.

Keywords Biodiversity - Kinorhyncha $\cdot$ East Asia · Morphology · Taxonomy

\section{Introduction}

Very recently, two new kinorhynch species were described and assigned to the new genus Meristoderes Herranz et al. 2012. One of them, Meristoderes macracanthus Herranz et al. 2012, is Mediterranean with type locality near Blanes, north of Barcelona in Spain. The species has furthermore been recorded from Sardinia, also in the Mediterranean (M. V. Sørensen personal observations). The second species, M. galatheae Herranz et al. 2012, was described almost from the opposite side of the globe, from localities around Ghizo Island, in the Solomon Island archipelago. The new genus could beyond any doubt be assigned to the family Echinoderidae, but species of the genus differs from other echinoderids in having segment 2 partially differentiated into a tergal and sternal plate (Herranz et al. 2012). This partial differentiation is in some species marked by distinct fissures, in others only by superficial subcuticular lines, in the lateroventral/ventrolateral parts of the segment. Since only two species have been known until now, and they were discovered so recently, our knowledge about morphology or geographical distribution of the genus is rather limited. 
The present contribution is part of the ongoing explorations of scalidophoran biodiversity around the Korean Peninsula (see also Sørensen et al. 2010a, b, c, 2012a, b, 2011; Lundbye et al. 2011). After addressing several other cyclorhagid genera in the previous studies, this contribution focuses on the occurrence of Meristoderes and presents data on no less than five new species of the genus. Four species were recorded with sufficient information to provide formal descriptions. The fifth species was only represented by a single specimen, and even though diagnostic characters are provided, it is too premature to present a formal description.

\section{Materials and methods}

The specimens used in the present study originate from numerous samples and collecting campaigns that have been carried out over a period of almost 10 years. An overview of the sampled stations that yielded specimens for this specific study is presented in Table 1, and the exact geographic positions of the stations are plotted in Fig. 1. Table 1 also provides information of sampling gear, sample processing, species collected and deposition of specimens. The naming of the stations follows the system introduced by Sørensen et al. (2012a) and used also by Sørensen et al. (2012b).

The collected specimens were always bulk fixated in $4 \%$ formalin, and specimens of the fixed samples were subsequently sorted to main group under a dissecting microscope. Kinorhynchs were picked up, transferred to formalin again, and later prepared for either light microscopy (LM) or scanning electron microscopy (SEM), following the standard procedures described by Sørensen and Pardos (2008). Specimens for LM were dehydrated through a graded series of glycerine, mounted on glass slides in Fluoromount-G, and examined with an Olympus BX51 microscope, equipped with an Olympus DP20 camera and a drawing tube. Specimens for (SEM) were dehydrated through a graded series of alcohol and then acetone, critical point dried, mounted on aluminium stubs, sputter coated with gold or a platinum/palladium mix and examined with a JEOL JSM-6335F Field Emission scanning electron microscope.

Usually species descriptions of kinorhynchs are based on LM observations, supplemented with information from SEM, but for the current study, only specimens mounted for SEM were available for some species. We do not consider this as a major problem, but in a few cases, it forced us to deviate from the standard procedure used in some of our previous species descriptions. For example, some of the provided line art illustrations are not based on camera lucida drafts, but are made as drawings, based on
SEM observations. Also the measures and dimensions are in some cases made on specimens mounted for SEM, which make them less precise. Such measures should only be seen as indicative rather than exact. Measures from SEM are not presented in tables together with statistical indices, but just reported in the text with a clear indication telling whether they are based on LM or SEM. Measures reported in tables originate solely from specimens mounted for LM. All measures, both on LM and SEM images, are made with Cell^D software. Segment lengths estimated from SEM photographs were made by measuring from the intersegmental joint on the preceding segment to the tip of the pectinate fringe on the following segment. The intersegmental joints were visible because the cuticle anterior to these points tended to be slightly collapsed inwards (see e.g. Fig. 10d). Otherwise, style and terminology generally follow all other recent contributions from the senior author.

The type specimens of M. macracanthus and M. galatheae were used for comparison. Type material of both species is stored at the Natural History Museum of Denmark (NHMD) under accession numbers ZMUC KIN-393 to KIN-396 and KIN-522 to KIN-529. Holotypes of new species described in the present study are deposited in the National Institute of Biological Resources, Korea (NIBR). Allotypes and paratypes are deposited at the NHMD (see Table 1 and descriptions below for further information).

\section{Results}

Taxonomic account

Order Cyclorhagida Zelinka, 1896

Family Echinoderidae Bütschli, 1876

Genus Meristoderes Herranz, Thormar, Benito, Sánchez

and Pardos 2012

Meristoderes herranzae new species (Figs. 2, 3, 4, 5; Table 2)

\section{Diagnosis}

Species with segments 1 and 2 consisting of closed rings, and segments 3-11 of one tergal and two sternal plates; segment 2, however, partly differentiated into one tergal and one sternal plate, with markings of incomplete tergosternal fissures in the lateroventral positions. Segment 2 with well-developed tubules in laterodorsal and ventrolateral positions; middorsal spines present on segments 4,6 and 8; tubules in lateroventral position on segment 5 , and spines in same positions on segments 6-9; tubules in lateral accessory position on segment 8 , and in laterodorsal position on segment 10. Tubules on segment 10 show sexual 


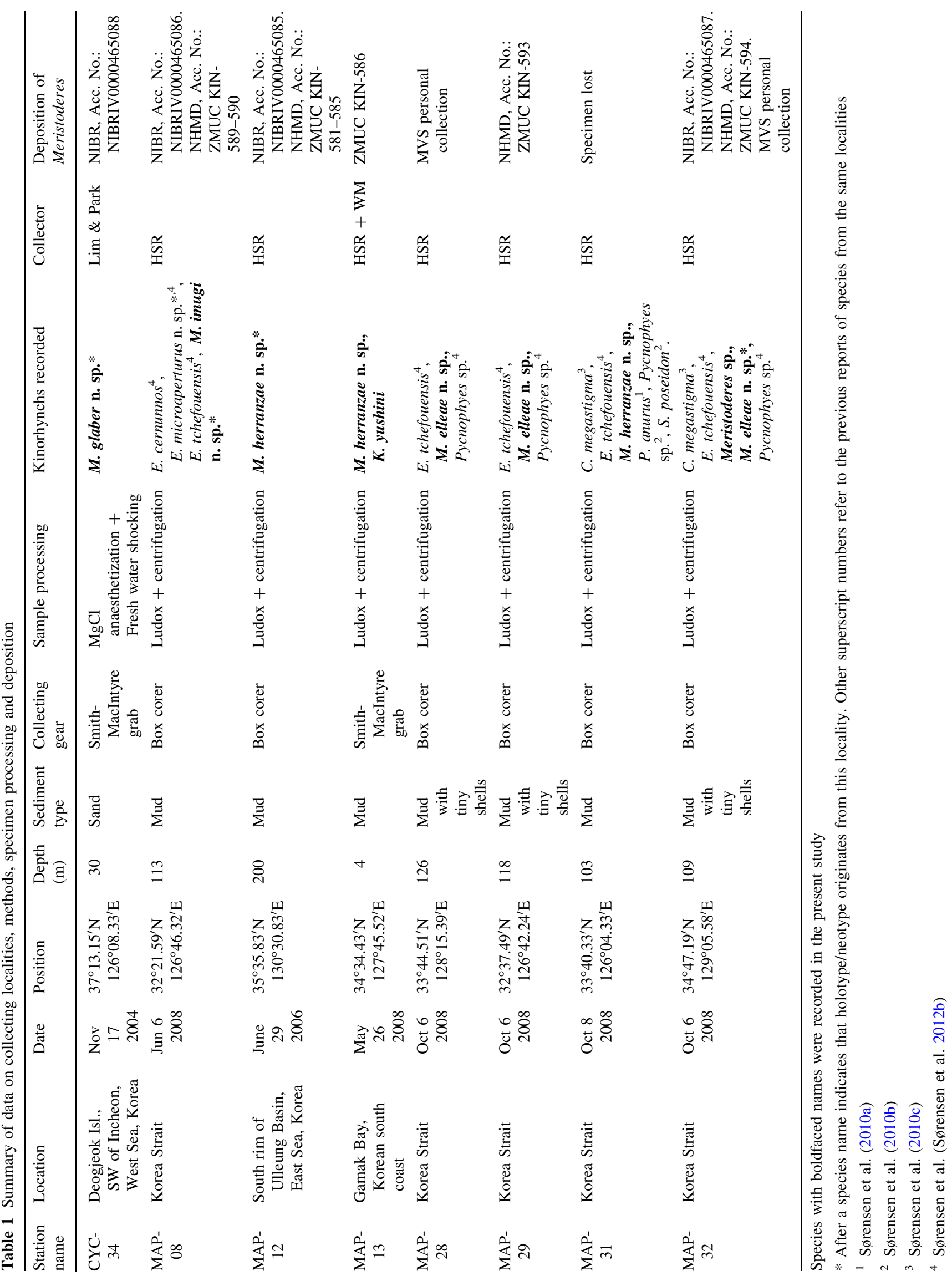




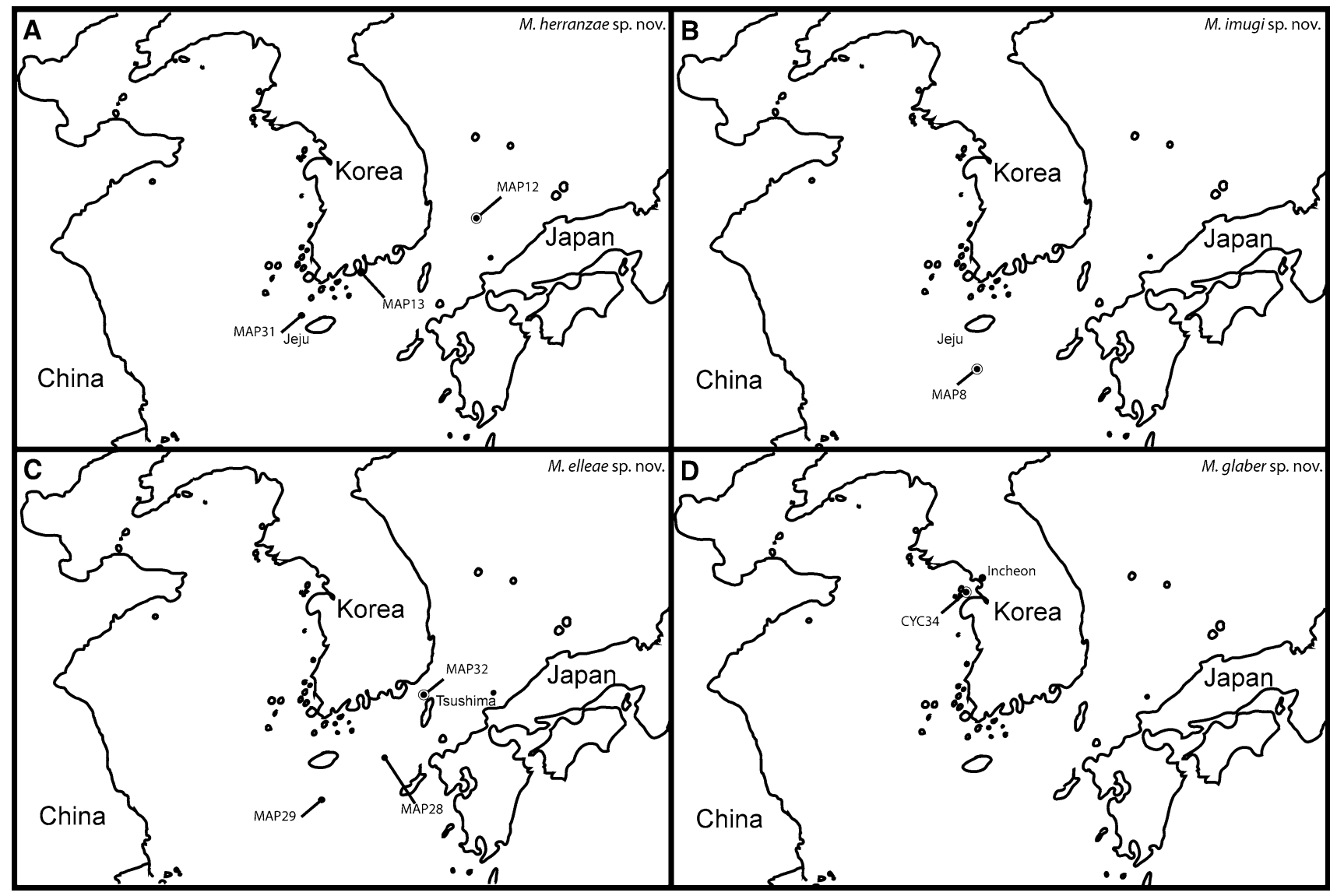

Fig. 1 Maps showing collecting localities for a M. herranzae sp. nov., b Meristoderes imugi sp. nov., c M. elleae sp. nov. and Meristoderes sp. (on MAP32 only), $\mathbf{d}$ M. glaber sp. nov. Type localities are marked with a ring around the dot

dimorphism, being large and well-developed in males, but short and sickle-shaped in females.

\section{Type material}

Holotype Adult female, collected with a box corer on 29 June 2006, at station MAP-12, on the south rim of the Ulleung Basin in the East Sea, (Fig. 1a), $35^{\circ} 35.83^{\prime} \mathrm{N}$, $130^{\circ} 30.83^{\prime} \mathrm{E}$, Korea, from mud at $200 \mathrm{~m}$ depth, mounted in Fluoromount-G, deposited at NIBR under accession number NIBRIV0000465085. Some of the segments on the holotype are slightly damaged; hence, the habitus illustration in Fig. 2 is partly based on camera lucida drawing of the holotype, and partly on reconstruction from specimens observed with SEM

Allotype Adult male, same collecting data as holotype, mounted for SEM, deposited at NHMD under accession number ZMUC KIN-581.

Paratypes one adult female and three juvenile stages, collected together with holotype and allotype, and mounted on same SEM stub as the allotype, deposited at NHMD under accession number ZMUC KIN-582 to KIN-585. One additional paratypic male from station MAP-13, collected with a Smith-MacIntyre grab on 26 May 2008, in Gamak Bay on the Korean south coast, (Fig. 1a), $34^{\circ} 34.43^{\prime} \mathrm{N}$, $127^{\circ} 45.52^{\prime} \mathrm{E}$, from subtidal mud at $4 \mathrm{~m}$ depth, mounted for SEM, deposited at NHMD under accession number ZMUC KIN-586. Additional material includes one male specimen, collected on 8 October 2008, at station MAP-31, in the Korea Strait, northwest of Jeju Island, (Fig. 1a), $33^{\circ} 40.33^{\prime} \mathrm{N}, 126^{\circ} 04.33^{\prime} \mathrm{E}$, Korea, from mud with tiny shells at $103 \mathrm{~m}$ depth. The specimen was mounted for SEM and was thoroughly photographed before it unfortunately detached from the SEM stub and got lost. The great difference in collecting depth for the holotype $(200 \mathrm{~m})$ and one paratype $(4 \mathrm{~m})$ is noteworthy, but not uncommon among species of Echinoderidae (see, e.g., Higgins and Kristensen 1988).

\section{Etymology}

The species is named after María Herranz-the discoverer and senior author of the genus Meristoderes. 
Fig. 2 Line art illustrations showing general habitus in $M$. herranzae sp. nov. a Female, dorsal view. b Female, ventral view. c Segments 10 and 11 in male, dorsal view. d Segments 10 and 11 in male, ventral view. gco 1 glandular cell outlet type 1, lat lateral accessory tubule, $l d$ laterodorsal sensory spot, $l d t$ laterodorsal tubule, ltas lateral terminal accessory spine, lts lateral terminal spine, lvs lateroventral spine, lvt lateroventral tubule, $m d s$ middorsal spine, $m v p$ midventral placid, $p d$ paradorsal sensory spot, ps penile spines, $s d$ subdorsal sensory spot, se sternal extension, te tergal extension, tsj tergosternal junction, $v l t$ ventrolateral tubule
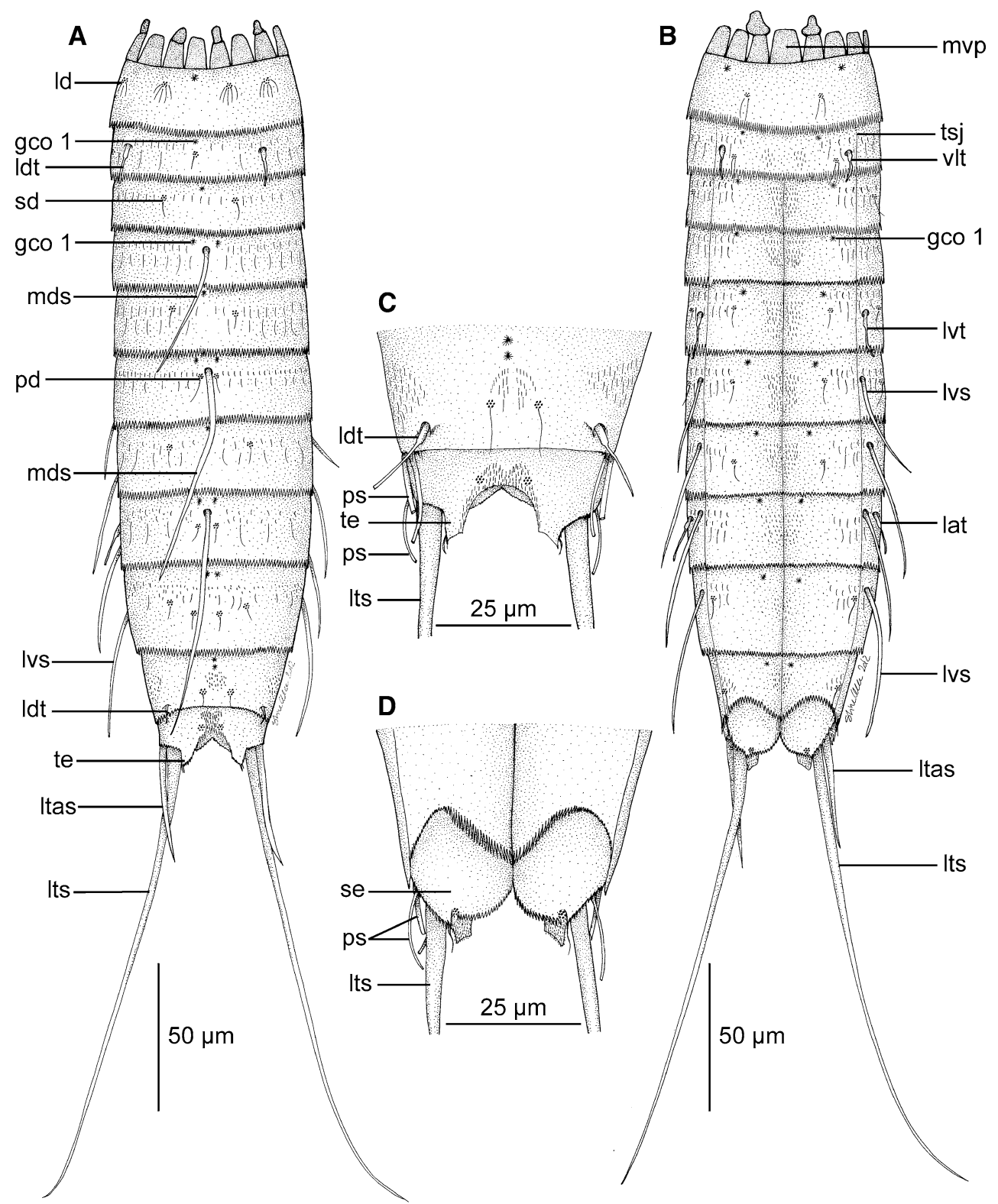

\section{Description}

Adult specimens consist of a head, a neck and eleven trunk segments (Figs. 2a, b, 4a, e). The trunk is approximately 240-268 $\mu \mathrm{m}$ (measures both from LM and SEM), and the trunk cuticle appears thin and flexible. A summary of sensory spot, tubule, spine, and glandular cell outlet positions is provided in Table 2.

The head consists of a retractable mouth cone and an introvert (Figs. 3, 4b). Inner armature of the mouth cone could not be examined in detail. The outer armature includes nine outer oral styles, each composed of two joined units. Base of each outer oral style with transverse fringe row. Introvert with 10 spinoscalids in Ring 01 (Fig. 3); spinoscalids composed of proximal sheath and distal end piece. Sheath with three transverse fringes: one weakly developed fringe most proximal, a well-developed fringe near the weakly developed one, and another welldeveloped one at the distal margin of the sheath. Distal end piece smooth and distally pointed. The remaining introvert armature is best described section-wise, rather than ringwise. The midventral section, section 1 , has eight scalids (Fig. 3), arranged as single (Rings 02, 04, 06 and 7) or in pairs (Rings 03 and 05). The two ventromedial sections, sections 2 and 10, have only five scalids each: In Rings 02 and 04 , a single, unpaired scalid is located in the centre of the section, whereas a pair is located in Ring 03. In Ring 05 , a single, but laterally displaced scalid is present (Fig. 3). The lateral displacement suggests that the scalid was part of a pair, but the attachment site of its putative 


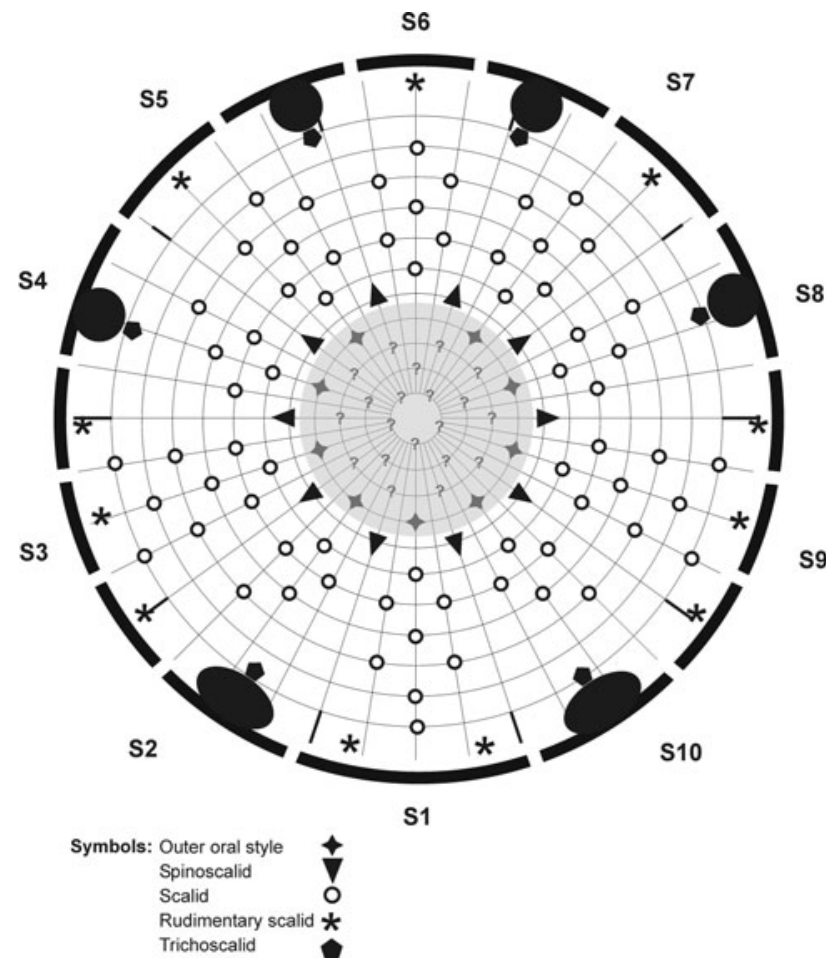

Fig. 3 Diagram of mouth cone (grey shaded area), introvert and placids in $M$. herranzae sp. nov. with indication of outer oral styles, scalid and placid distribution. Placids and trichoscalid plates are symbolized by the black-shaded bent bars and circles around the introvert diagram

counterpart is covered and occupied by the large trichoscalid plate. Sections 3 and 9 (Fig. 4b) have nine scalids, alternatingly arranged as singletons and pairs, starting with a single scalid in Ring 02 (Fig. 3). Sections 4 and 8 (Fig. 4b) resemble sections 2 and 10, having only five scalids, and the position of a putative sixth one in Ring 05 occupied by a trichoscalid plate. The sub- and middorsal sections, sections 5-7, are identical, displaying seven scalids, alternatingly arranged as singletons and pairs, starting with a single scalid in Ring 02 (Fig. 3).

The neck consists of 16 placids (Fig. 3), all measuring $12-13 \mu \mathrm{m}$ in length and $7 \mu \mathrm{m}$ in width at bases, except midventral placid (Fig. 5b) that measures $11 \mu \mathrm{m}$ in width (all measures from LM; hereafter "LM" or "SEM" will indicate how the measure was made). Placids in positions corresponding to introvert sections 2 and 10 with broad trichoscalid plates; smaller, elongate trichoscalid plates associated with placids in positions corresponding to introvert sections 4, 5, 7 and 8 (Figs. 3, 5a). A small, rudimentary scalid is attached anterior to each placid without trichoscalid plates (Fig. 4b); the broad, midventral placid has two of such rudimentary scalids.

Segment $1(26 \mu \mathrm{m}, \mathrm{LM})$ consists of one complete cuticular ring. Pairs of subdorsal, laterodorsal (Figs. 2a, 4d, f, 5a) and ventromedial sensory spots present. Sensory spots are fairly large, rounded, with numerous papillae and a central and a lateral pore; sub- and laterodorsal sensory spots (Fig. 4d, f) with long, marginal cuticular hairs. Cuticular hairs are otherwise not present on the segment. Glandular cell outlet type 1 (gcol) present as a single, unpaired pore field in middorsal position (Figs. 2a, 4d, 5a) and as a pair in lateroventral positions. Posterior margin terminates into a regular pectinate fringe.

Segment $2(24 \mu \mathrm{m}, \mathrm{LM})$ appears as a complete cuticular ring, but has markings of incomplete tergosternal fissures in the lateroventral position (Fig. 4c). A midventral fissure is not indicated. Tubules $(16 \mu \mathrm{m}, \mathrm{SEM})$ are present in laterodorsal and ventrolateral positions (Figs. 2a, b, 4c, d, $5 \mathrm{a}, \mathrm{b}$ ), pore fields (gco1) in middorsal (Figs. 2a, 4d) and ventromedial positions, and sensory spots in middorsal (Figs. 4d, 5a), midlateral (Fig. 4c, d, g) and ventromedial positions. Sensory spots on this and all following segments are rounded (Fig. 4g) and have one central pore, and one long and prominent cuticular hair (which occasionally breaks off). Other cuticular hairs are bracteate and appear in one anterior row with relatively short hairs, and a more posterior row with longer hairs (Fig. 4c, d); all hairs on this the following segments with a peculiar appearance, namely with one tiny side-branch and bifurcating tips. Both rows stretch over the dorsal and lateral sides, with a short midlateral interruption, and end in the ventromedial position. Additional few, short hairs are located in paired paraventral patches. A well-developed secondary fringe with minute fringe tips wraps around the anterior part of the segment. Posterior segment margin as on preceding segment.

Segment $3(27 \mu \mathrm{m}, \mathrm{LM})$ and all following segments consist of one tergal and two sternal plates (Fig. 2a, b). Segment with sensory spots in subdorsal and sublateral positions, and unpaired middorsal (Figs. 2a, 4d) and paired ventromedial pore fields (gco1). Cuticular hairs, secondary fringe and posterior segment margin as on preceding segment, except for paraventral areas that now have two patches of densely set filiform cuticular extensions (sensu Thormar and Sørensen 2010).

Segment $4(32 \mu \mathrm{m}, \mathrm{LM})$ with long middorsal spine (55 $\mu \mathrm{m}$, SEM) (Figs. 2a, 4d, e). Pore fields (gco1) present in paradorsal (Fig. 4d) and ventromedial positions. Sensory spots not present. Pectinate fringe and secondary fringe as on preceding segment. Cuticular hairs also as on preceding segment, but the transverse bands are now also interrupted middorsally.

Segment $5(33 \mu \mathrm{m}, \mathrm{LM})$ with lateroventral tubules (15 $\mu \mathrm{m}$, SEM) (Fig. 2b). Pore fields (gco1) present in middorsal and ventromedial positions. Sensory spots in subdorsal, sublateral and ventromedial positions. Cuticular hairs, secondary fringe and pectinate fringe as on preceding segment. 

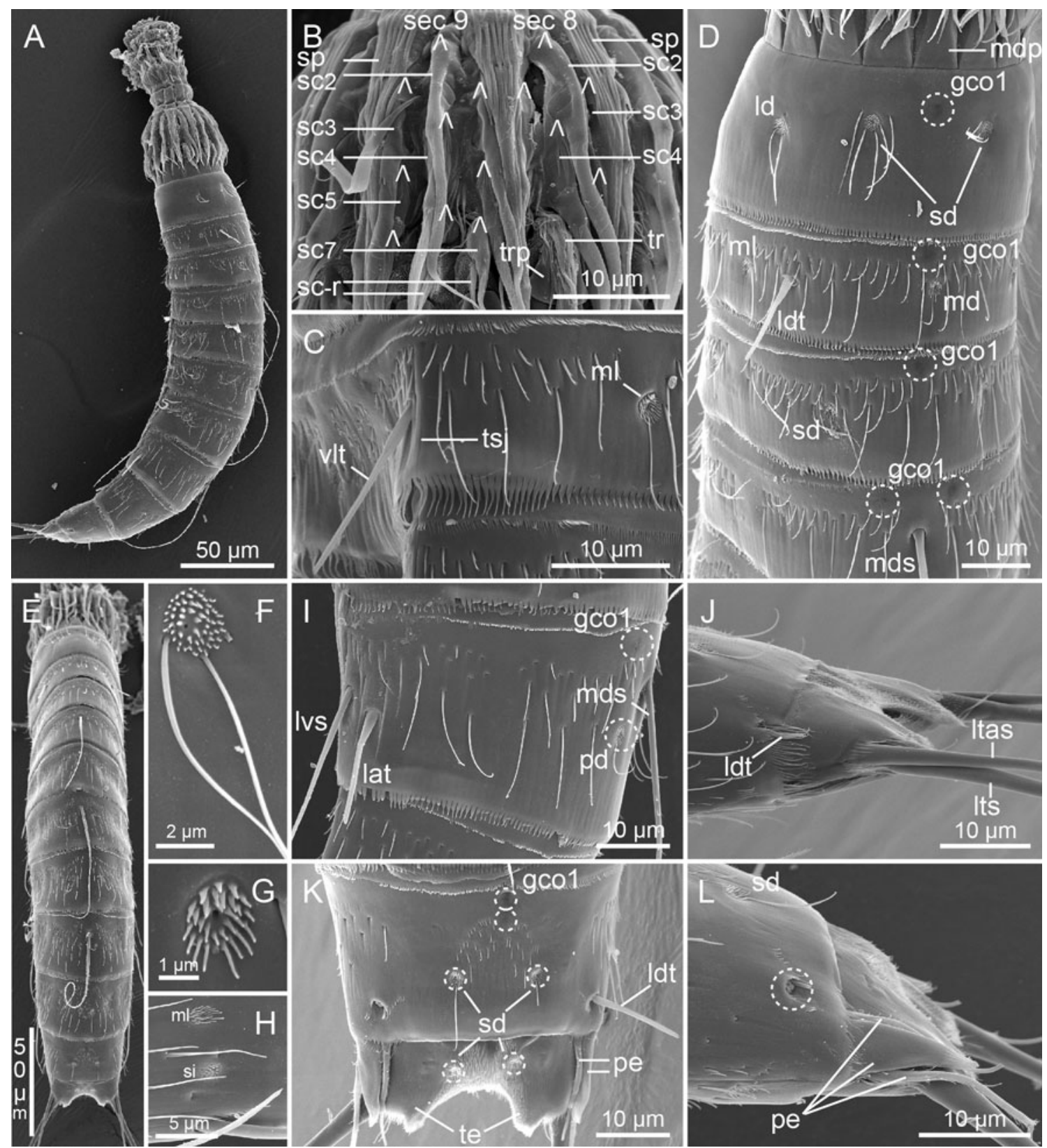

Fig. 4 Scanning electron micrographs showing overviews and details in head and trunk morphology of M. herranzae sp. nov. a Lateral overview of whole specimen. b Detail of head showing introvert sections 8 and 9. c Segment 2, lateroventral and ventrolateral positions. d Segments $1-4$, subdorsal view. e Dorsal overview of whole specimen. f Laterodorsal sensory spot on segment 1. g Midlateral sensory spot on segment 2 . h Midlateral sensory spot and sieve plate on segment 9. i Segment 8, lateral view. j Segment 10 and 11 in female, lateral view. k Segment 10 and 11 in male, dorsal view. 1 Segment 10 and 11 in male, lateral view (note that the laterodorsal tubule is broken off, leaving the scar inside the dashed circle). gco 1 glandular cell outlet type 1, lat lateral accessory tubule, ld laterodorsal sensory spot, ldt laterodorsal tubule, ltas lateral terminal accessory spine, lts lateral terminal spine, $l v s$ lateroventral spine, $m d$ middorsal sensory spot, $m d p$ middorsal placid, $m d s$ middorsal spine, $m l$ midlateral sensory spot, $p e$ penile spines, $p d$ paradorsal sensory spot, $s c$ scalids, sc-r scalid rudiment, sd subdorsal sensory spot, sec $8 / 9$ introvert section 8/9, si sieve plate, $s p$ spinoscalids, te tergal extension, $t r$ trichoscalid, trp trichoscalid plate, $t s j$ tergosternal junction, vlt ventrolateral tubule. Digits after labels refer to the introvert ring numbers on b. Lambda symbols $\Lambda$ mark attachment point of scalids
Segment $6(33 \mu \mathrm{m}, \mathrm{LM})$ with single middorsal $(68 \mu \mathrm{m}$, SEM) (Figs. 2a, 4e) and paired lateroventral spines (27 $\mu \mathrm{m}$, SEM) (Fig. 2b). Paired pore fields (gco1) present anterior to attachment point of the middorsal spine; one additional pair present in ventromedial positions. Sensory spots present in paradorsal, sublateral, and ventromedial 

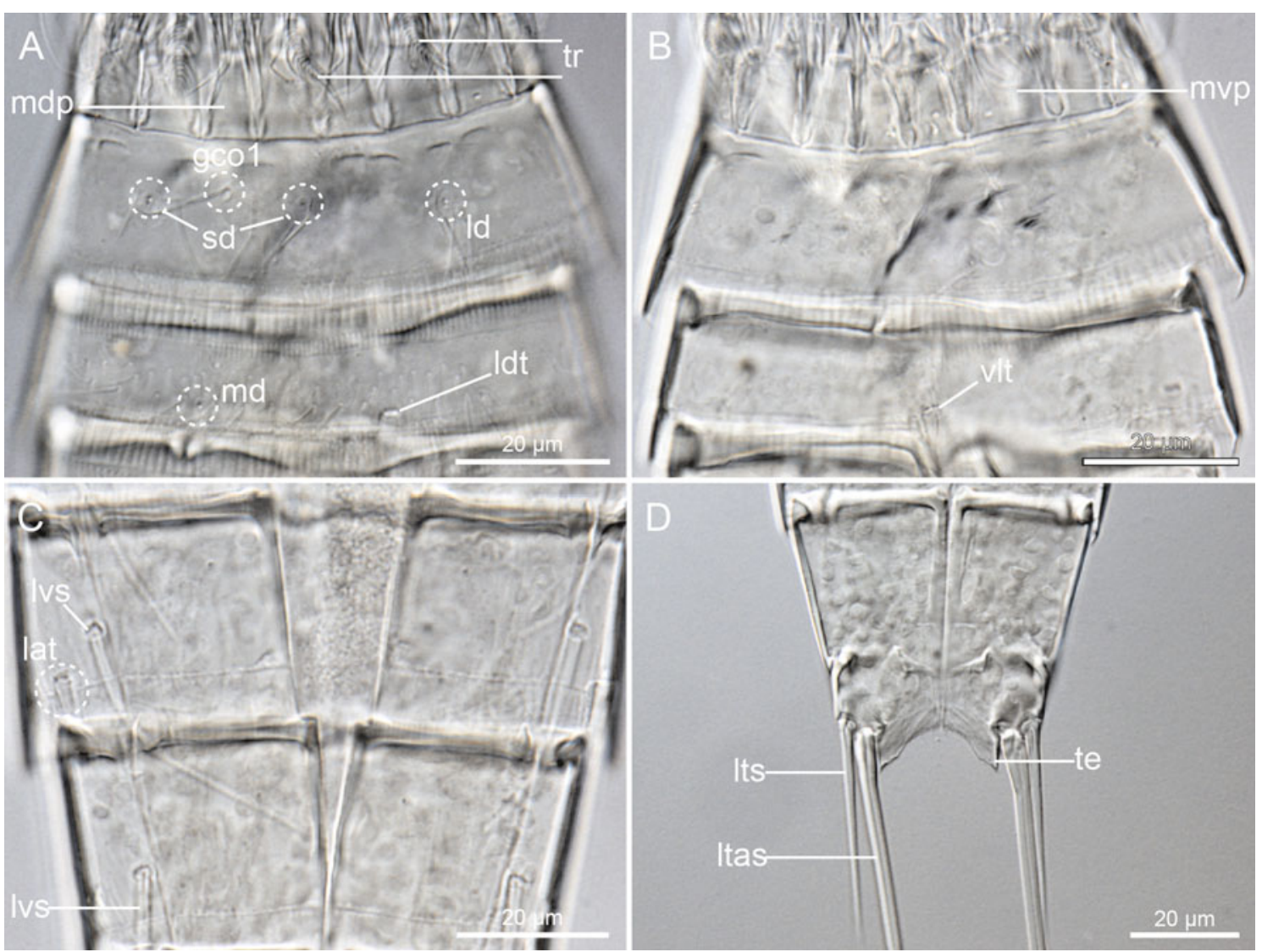

Fig. 5 Light micrographs showing details of neck and trunk morphology in female holotype of M. herranzae sp. nov., NIBR Acc. No. NIBRIV0000465085. a Neck and segments 1 and 2, dorsal view. b Neck and segments 1 and 2, ventral view. c Segments 8 and 9, ventral view. d Segments 10 and 11 and terminal spines. gco 1 glandular cell outlet type 1 , lat lateral accessory tubule, $l d$

laterodorsal sensory spot, ldt laterodorsal tubule, ltas lateral terminal accessory spine, lts lateral terminal spine, lvs lateroventral spine, $m d$ middorsal sensory spot, $m d p$ middorsal placid, $m v p$ midventral placid, $s d$ subdorsal sensory spot, te tergal extension, $t r$ trichoscalid, vlt ventrolateral tubule

Table 2 Summary of nature and location of sensory spots, glandular cell outlets, tubules and spines arranged by series in M. herranzae sp. nov. from the East Sea, Korea

\begin{tabular}{|c|c|c|c|c|c|c|c|c|c|c|c|}
\hline $\begin{array}{l}\text { Position } \\
\text { segment }\end{array}$ & MD & PD & SD & LD & ML & SL & LA & LV & VL & VM & PV \\
\hline 1 & gco1 & & ss & ss & & & & gco1 & & ss & \\
\hline 2 & gco1, ss & & & tu & ss & & & & tu & gco1, ss & \\
\hline 3 & gcol & & ss & & & ss & & & & gco1 & \\
\hline 4 & ac & gco1 & & & & & & & & gco1 & \\
\hline 5 & gco1 & & ss & & & ss & & tu & & ss, gco 1 & \\
\hline 6 & ac & gco1, ss & & & & ss & & ac & & ss, gco1 & \\
\hline 7 & gcol & & Ss & & & ss & & ac & & ss, gco1 & \\
\hline 8 & ac & $\mathrm{gco} 1, \mathrm{ss}$ & & & & & tu & ac & & & gcol \\
\hline 9 & & $\mathrm{gco} 1, \mathrm{ss}$ & ss & & ss & & si & ac & ss & & gco1 \\
\hline 10 & gco1, gco1 & & ss & tu & & & & & ss & & gco1 \\
\hline 11 & & & ss & & & & ltas (f) & lts & & ss & \\
\hline
\end{tabular}

$L A$ lateral accessory, $L D$ laterodorsal, $L V$ lateroventral, $M D$ middorsal, $M L$ midlateral, $P D$ paradorsal, $P V$ paraventral, $S D$ subdorsal, $S L$ sublateral, $V L$ ventrolateral, $V M$ ventromedial, $a c$ acicular spine, $f$ female condition of sexual dimorphic character, $g c o 1$ glandular cell outlet type I, ltas lateral terminal accessory spine, lts lateral terminal spine, si sieve plate, $s s$ sensory spot, tu tubule 
Fig. 6 Line art illustrations showing general habitus in Meristoderes imugi sp. nov. Please note that glandular cell outlets type 1 were difficult to visualize in this specimen, and that some may be missing on the illustration. a Female, dorsal view. b Female, ventral view. c Segments 10 and 11 in male, dorsal view. d Segments 10 and 11 in male, ventral view. gco 1 glandular cell outlet type 1 , ld laterodorsal sensory spot, ldt laterodorsal tubule, ltas lateral terminal accessory spine, lts lateral terminal spine, lvs lateroventral spine, lvt lateroventral tubule, $m d p$ middorsal placid, $m d s$ middorsal spine, $m l$ midlateral sensory spot, $m t j$ midtergal junction, $m v p$ midventral placid, $p d$ paradorsal sensory spot, $p s$ penile spines, $s d$ subdorsal sensory spot, $s d t$ subdorsal tubule, se sternal extension, slt sublateral tubule, te tergal extension, $t s j$ tergosternal junction, $v l t$ ventrolateral tubule
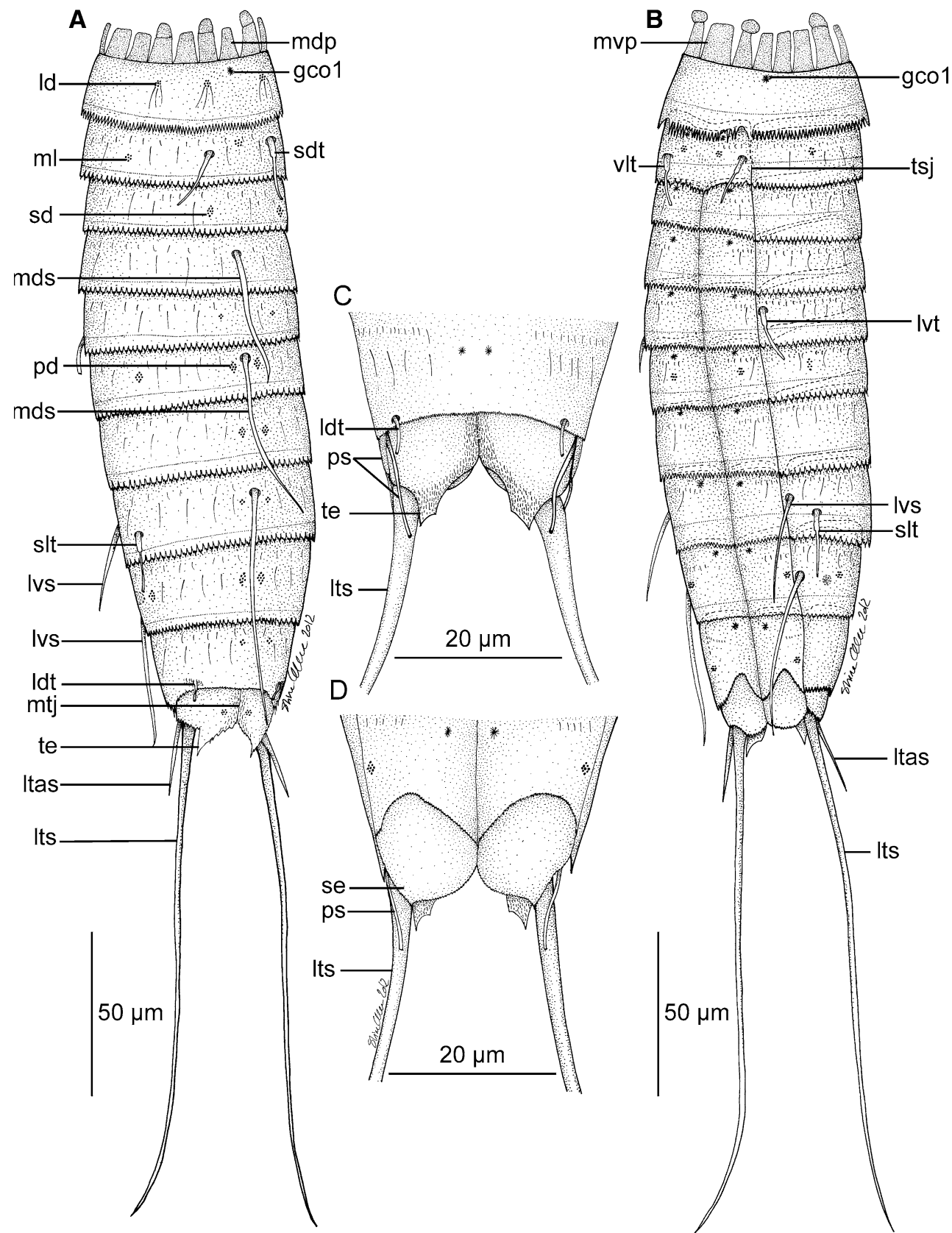

positions; paradorsal ones slightly posterior to attachment point of the middorsal spine. Cuticular hairs, secondary fringe and pectinate fringe as on preceding segment.

Segment $7(32 \mu \mathrm{m}, \mathrm{LM})$ with lateroventral spines (33 $\mu \mathrm{m}$, SEM) (Fig. 2b). Unpaired pore field (gco1) in middorsal position, and paired ones in ventromedial positions, but close to the paraventral area. Sensory spots present in subdorsal, sublateral, and ventromedial positions. Cuticular hairs, secondary fringe and pectinate fringe as on preceding segment.

Segment $8(36 \mu \mathrm{m}, \mathrm{LM})$ with single middorsal spine (69 $\mu \mathrm{m}, \mathrm{SEM}$ ) (Figs. 2a, 4e, i), paired lateroventral spines
(35 $\mu \mathrm{m}, \mathrm{SEM})$, and paired lateral accessory tubules (16 $\mu \mathrm{m}, \mathrm{SEM}$ ) (Figs. 2b, 4i, 5c). Paired pore fields (gco1) present anterior to attachment point of the middorsal spine (Fig. 4i); one additional pair present in paraventral position. Sensory spots present in paradorsal position only (Fig. 4i). The two rows of cuticular hairs are more diffuse and appear more like a broader transverse band of hairs, but still with the longest hairs most posteriorly (Fig. 4i). The filiform cuticular extensions in the paraventral patches appear very short compared to preceding segments. Pectinate fringe and secondary fringe as on preceding segment. 

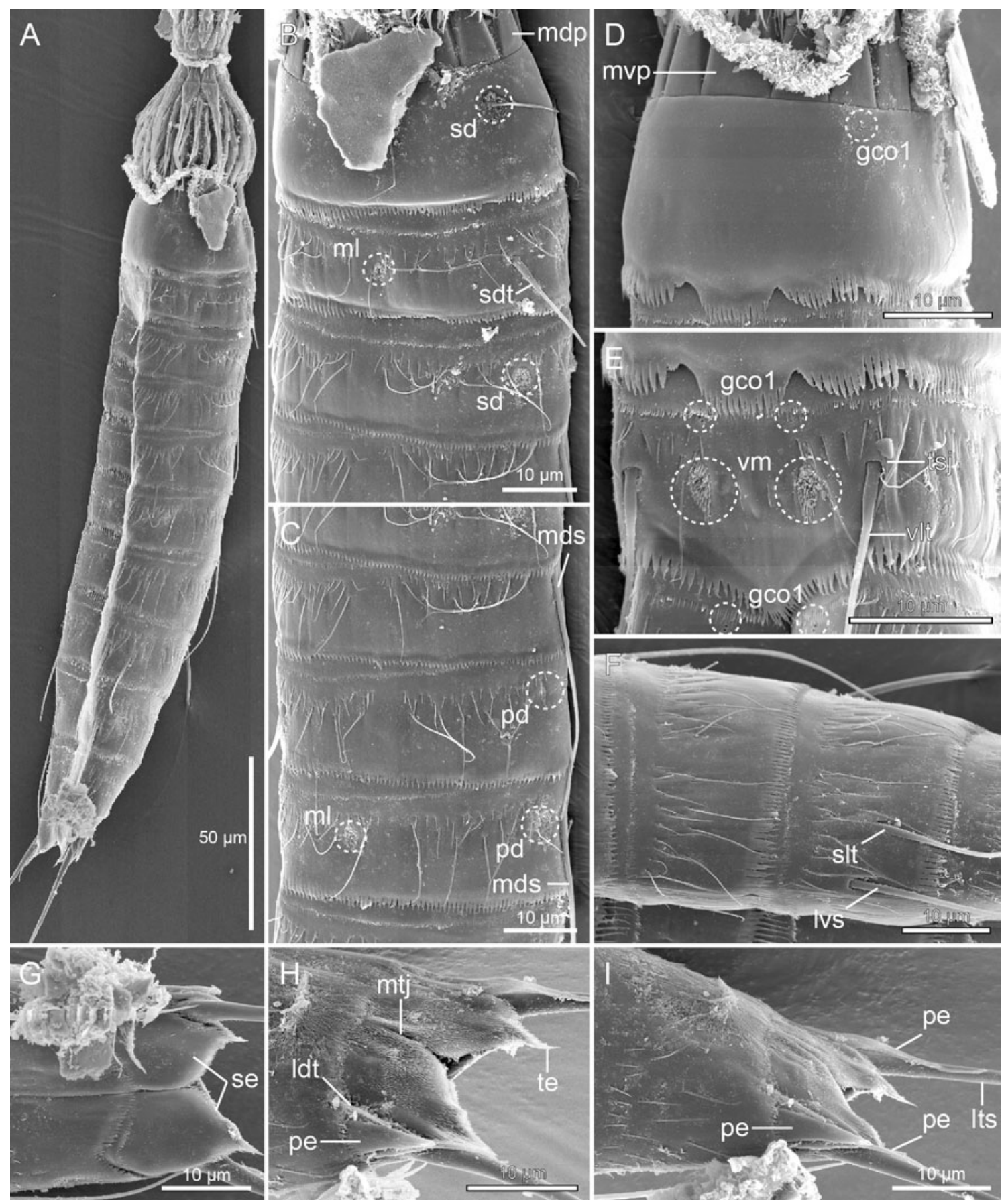

Fig. 7 Scanning electron micrographs showing overviews and details in head and trunk morphology of male Meristoderes imugi sp. nov. a Lateral overview of whole specimen. b Segments 1-4, midlateral view. c Segments 4 to 6 , midlateral view. d Neck and segment 1, ventral view. e Segment 2, ventrolateral view. f Segments 7 and 8, midlateral view. g Segments 10 and 11, ventral view. h Segment 11, laterodorsal view. i Segments 10 and 11, midlateral view. gco 1

Segment $9(39 \mu \mathrm{m}, \mathrm{LM})$ with lateroventral spines (41 $\mu \mathrm{m}$, SEM) (Figs. 2b, 5c). Paired pore fields (gco1) present in paradorsal and paraventral positions. Sensory spots present in paradorsal, subdorsal, midlateral (Fig. 4h) glandular cell outlet type 1 , ldt laterodorsal tubule, lts lateral terminal spine, $l v s$ lateroventral spine, $m d p$ middorsal placid, $m d s$ middorsal spine, $m l$ midlateral sensory spot, $m t j$ midtergal junction, $m v p$ midventral placid, $p d$ paradorsal sensory spot, $p e$ penile spine, $s d$ subdorsal sensory spot, $s d t$ subdorsal tubule, se sternal extension, slt sublateral tubule, te tergal extension, tsj tergosternal junction, $v l t$ ventrolateral tubule, $v m$ ventromedial sensory spot

and ventrolateral positions. Rounded sieve plates, apparently bearing minute papillae, present in lateral accessory positions (Fig. 4h). Cuticular hairs, secondary fringe and pectinate fringe as on preceding segment; filiform cuticular 

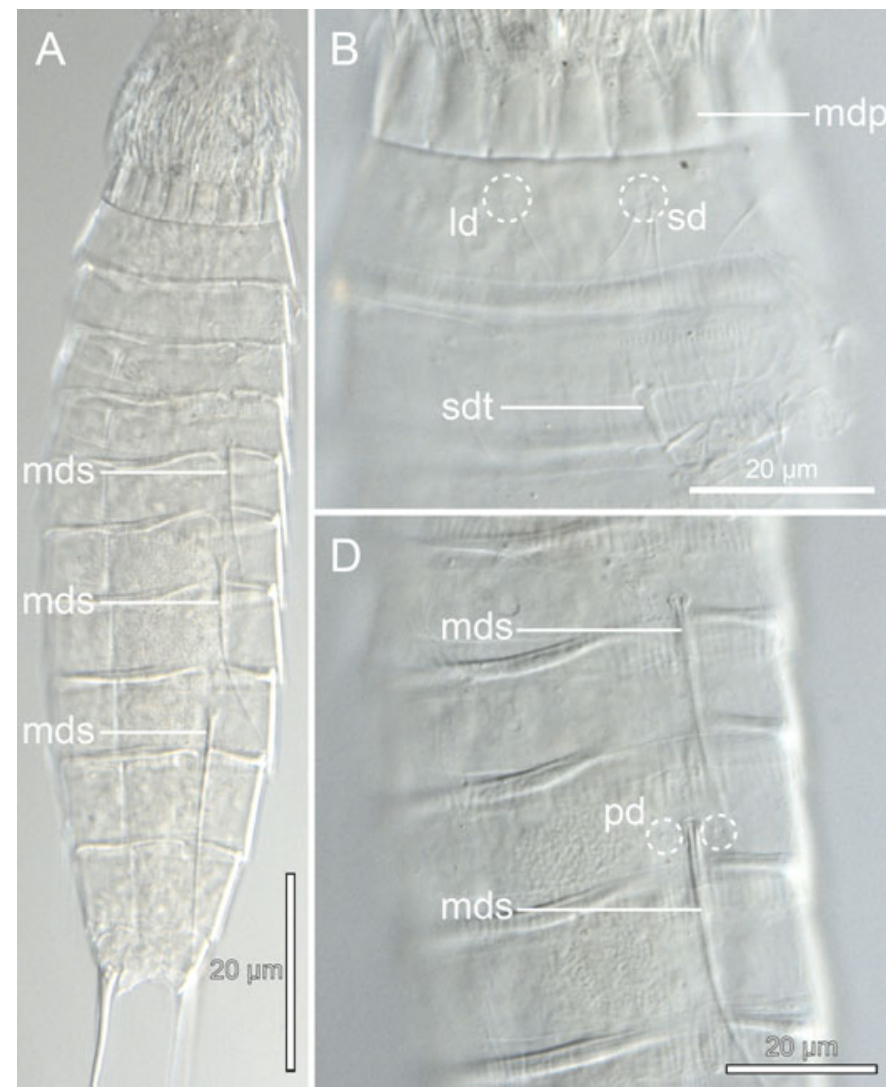

$l d$ laterodorsal sensory spot, $l v s$ lateroventral spine, $m d p$ middorsal placid, $m d s$ middorsal spine, $m l$ midlateral sensory spot, $m v p$ midventral placid, $p d$ paradorsal sensory spot, $s d$ subdorsal sensory spot, sdt subdorsal tubule, si sieve plate, slt sublateral tubule, $t s j$ tergosternal junction, $v l t$ ventrolateral tubule

spines in males (Figs. 2c, d, 4k, 1). Dorsal and ventral penile spines appear regular tubular (dorsal ps $15 \mu \mathrm{m}$, ventral ps $19 \mu \mathrm{m}, \mathrm{SEM})$, whereas the median spine is strongly modified into a very stout, triangular or coneshaped structure $(12 \mu \mathrm{m}$ long and $5 \mu \mathrm{m}$ broad at base, SEM), with distal wrinkles or a superficial fringe (Fig. 41). Sensory spots present in subdorsal position (Fig. 4k), and ventromedially on the posterior margins of the sternal extensions. Secondary fringe and cuticular hairs not present, but filiform cuticular extensions present in mid- and paradorsal areas, and in a narrow midventral band. Tergal extensions are short with interrupted mesial margins (Fig. 5d); sternal extensions short and rounded.

\section{Juvenile morphology}

All juvenile specimens available for examination represent the same juvenile stage, probably stage 5 . The specimens have 11 trunk segments, but their overall morphology 
Table 3 Measurements of female holotype and paratype of Meristoderes imugi sp. nov. from the Korea Strait

\begin{tabular}{lll}
\hline Character & $\begin{array}{l}\text { Length } \\
\text { holotype }\end{array}$ & $\begin{array}{l}\text { Length } \\
\text { paratype }\end{array}$ \\
\hline TL & $206 \mu \mathrm{m}$ & $199 \mu \mathrm{m}$ \\
MSW-8 & $35 \mu \mathrm{m}$ & - \\
MSW-8/TL & $17.0 \%$ & - \\
SW-10 & $30 \mu \mathrm{m}$ & - \\
SW-10/TL & $14.6 \%$ & - \\
S1 & $17 \mu \mathrm{m}$ & $19 \mu \mathrm{m}$ \\
S2 & $19 \mu \mathrm{m}$ & $20 \mu \mathrm{m}$ \\
S3 & $22 \mu \mathrm{m}$ & $24 \mu \mathrm{m}$ \\
S4 & $25 \mu \mathrm{m}$ & $27 \mu \mathrm{m}$ \\
S5 & $25 \mu \mathrm{m}$ & $28 \mu \mathrm{m}$ \\
S6 & $26 \mu \mathrm{m}$ & $29 \mu \mathrm{m}$ \\
S7 & $27 \mu \mathrm{m}$ & $30 \mu \mathrm{m}$ \\
S8 & $29 \mu \mathrm{m}$ & $32 \mu \mathrm{m}$ \\
S9 & $31 \mu \mathrm{m}$ & $31 \mu \mathrm{m}$ \\
S10 & $25 \mu \mathrm{m}$ & $28 \mu \mathrm{m}$ \\
S11 & $21 \mu \mathrm{m}$ & $23 \mu \mathrm{m}$ \\
MD4 (ac) & $38 \mu \mathrm{m}$ & $40 \mu \mathrm{m}$ \\
MD6 (ac) & $50 \mu \mathrm{m}$ & $54 \mu \mathrm{m}$ \\
MD8 (ac) & $68 \mu \mathrm{m}$ & $70 \mu \mathrm{m}$ \\
SD2 (tu) & $12 \mu \mathrm{m}$ & - \\
VL2 (tu) & $15 \mu \mathrm{m}$ & $16 \mu \mathrm{m}$ \\
LV5 (tu) & $15 \mu \mathrm{m}$ & $16 \mu \mathrm{m}$ \\
ML8 (tu) & $20 \mu \mathrm{m}$ & $24 \mu \mathrm{m}$ \\
LV8 (ac) & $29 \mu \mathrm{m}$ & $34 \mu \mathrm{m}$ \\
LV9 (ac) & $45 \mu \mathrm{m}$ & $43 \mu \mathrm{m}$ \\
LTS & $134 \mu \mathrm{m}$ & $138 \mu \mathrm{m}$ \\
LTS/TL & $65.0 \%$ & $69.3 \%$ \\
LTAS (f) & $22 \mu \mathrm{m}$ & N/A \\
\hline S & acicur & - \\
\hline
\end{tabular}

ac acicular spine, $f$ female condition of sexual dimorphic character, $L T A S$ lateral terminal accessory spine, $L T S$ lateral terminal spine, $L V$ lateroventral, $M D$ middorsal, $M L$ midlateral, $M S W-8$ maximum sternal width, measured on segment 8 in this species, $S$ segment lengths, $S D$ subdorsal, $S W-10$ standard width, always measured on segment $10, T L$ trunk length, $t u$ tubule, $V L$ ventrolateral

displays typical juvenile traits, such as midsternal plates on segments 2-11, and postmarginal spiculae on segment margins. The neck region is composed of 16 placids, but there is no distinct articulation between the placids and segment 1 . Middorsal spines are present in segments 4, 6 and 8 , as in adults, and in addition on segment 9. The lateral series show a lateroventral tubule on segment 5, lateroventral spines on segments $6-9$, and a lateral accessory tubule on segment 8 . Laterodorsal tubules are present on segment 2, but ventrolateral ones are not. A pair of strong lateroventral spines is present on segment 10 , next to a pair of much shorter tubules. Terminal segment with a pair of long, and an additional pair of much shorter, lateral terminal spines.

Meristoderes imugi new species, (Figs. 6, 7, 8; Tables 3, 4)

\section{Diagnosis}

Species with segment 1 consisting of a closed cuticular ring; segment 2 consisting of a tergal and a sternal plate, and tergosternal fissures being distinct with both SEM and LM; segments 3-10 of one tergal and two sternal plates, and segment 11 of two tergal and two sternal plates. Segment 2 with well-developed tubules in subdorsal and ventrolateral positions; middorsal spines present on segments 4,6 and 8 ; tubules in lateroventral position on segment 5 , and spines in same positions on segments 8 and 9; tubules also in sublateral position on segment 8 , and in laterodorsal position on segment 10. Tubules on segment 10 show sexual dimorphism, being large and well-developed in males, but shorter and less developed in females.

\section{Type material}

Holotype Adult female, collected with a box corer on 6 June 2008, at station MAP-8, ca. $100 \mathrm{~km}$ south of Jeju Island, (Fig. 1b), $32^{\circ} 21.59^{\prime} \mathrm{N}, 126^{\circ} 46.32^{\prime} \mathrm{E}$, from mud at $113 \mathrm{~m}$ depth, mounted in Fluoromount-G, deposited at NIBR under accession number NIBRIV0000465086.

Allotype Adult male, same collecting data as holotype, mounted for SEM, deposited at NHMD under accession number ZMUC KIN-589; allotype mounted on same SEM stub as six specimens of Echinoderes microaperturus (KIN-591) and four of E. tchefouensis (KIN-592).

Paratype Adult female, same collecting data as holotype, mounted on its lateral side in Fluoromount-G, deposited at NHMD under accession number ZMUC KIN-590.

\section{Etymology}

The species is named after the "imugi"-a dragon-like creature from Korean mythology. According to the myths, imugis live in the oceans. They are not yet true dragons, but giant serpents with the potential to turn into dragons over time.

\section{Description}

Adult specimens consist of a head, a neck and eleven trunk segments (Figs. 6a, b, 7a, 8a). The trunk cuticle appears thin and flexible. Measurements and dimensions (all based on LM) are given in Table 3, and a summary of sensory 
Table 4 Summary of nature and location of sensory spots, glandular cell outlets, tubules and spines arranged by series in Meristoderes imugi sp. nov. from the Korea Strait

\begin{tabular}{|c|c|c|c|c|c|c|c|c|c|c|c|}
\hline $\begin{array}{l}\text { Position } \\
\text { segment }\end{array}$ & MD & PD & SD & LD & ML & SL & LA & LV & VL & VM & PV \\
\hline 1 & gcol & & ss & ss & & & & gcol & & & \\
\hline 2 & Ss & & tu & & ss & & & & tu & gco1, ss & \\
\hline 3 & & & $\mathrm{ss}^{\mathrm{b}}$ & & & & & & & gco1 & \\
\hline 4 & $\mathrm{ac}$ & & & & & & & & & gco1 & \\
\hline 5 & & $\mathrm{ss}^{\mathrm{a}}$ & & & & & & tu & & gco1 & \\
\hline 6 & $\mathrm{ac}$ & $\mathrm{ss}^{\mathrm{b}}$ & & & $\mathrm{ss}^{\mathrm{b}}$ & & & & & ss, gco1 & \\
\hline 7 & & $\mathrm{ss}^{\mathrm{b}}$ & & & & & & & & gco1 & \\
\hline 8 & $\mathrm{ac}$ & $\mathrm{ss}^{\mathrm{a}}$ & & & & tu & & ac & & & gcol \\
\hline 9 & & ss & & & ss & $\mathrm{si}$ & & ac & ss & & gcol \\
\hline 10 & & & ss & tu & & & & & ss & & gcol \\
\hline 11 & & & ss & & & & $\operatorname{ltas}(\mathrm{f})$ & lts & & & \\
\hline
\end{tabular}

Please note that glandular cell outlets type 1 were difficult to visualize in this specimen, and that some may be missing in the table summary. $L A$ lateral accessory, $L D$ laterodorsal, $L V$ lateroventral, $M D$ middorsal, $M L$ midlateral, $P D$ paradorsal, $P V$ paraventral, $S D$ subdorsal, $S L$ sublateral, $V L$ ventrolateral, $V M$ ventromedial, $a c$ acicular spine, $f$ female condition of sexual dimorphic character, $g c o l$ glandular cell outlet type I, ltas lateral terminal accessory spine, lts lateral terminal spine, si sieve plate, ss sensory spot ( ${ }^{\mathrm{a}}$ - that they are conspicuously small, ${ }^{\mathrm{b}}$ - marks that they are conspicuously large); $t u$ tubule

spot, tubule, spine, and glandular cell outlet positions is provided in Table 4. Glandular cell outlets of type 1 generally appeared very weak in both LM and SEM; hence some, especially on the dorsal side, could have been missed during examination.

The head consists of a retractable mouth cone and an introvert. Inner armature of the mouth cone could not be examined in detail. The outer armature includes nine outer oral styles, each composed of two joined units. Bases of each outer oral style with a narrow fringe row. The introvert of the single specimen available for SEM was too dirty to be examined in detail.

The neck consists of 16 placids (Fig. 8b), all measuring $10-11 \mu \mathrm{m}$ in length and $7 \mu \mathrm{m}$ in width at bases, except midventral placid that measures $8 \mu \mathrm{m}$ in width (Fig. $8 \mathrm{c}$ ). Placids in positions corresponding to introvert sections 2 and 10 with trichoscalid plates; slightly smaller trichoscalid plates associated with placids in positions corresponding to introvert sections $4,5,7$ and 8 .

Segment 1 consists of one complete cuticular ring. Pairs of subdorsal and laterodorsal sensory spots present (Figs. 6a, 7b, 8b, c). Sensory spots are rounded, with numerous papillae and with long, marginal cuticular hairs. Cuticular hairs are otherwise not present on the segment (Fig. 7b, d). Glandular cell outlet type 1 (gco1) present as a single, unpaired pore field in middorsal position and as a pair in lateroventral positions (Fig. 7d). Posterior margin terminates into a regular pectinate fringe.

Segment 2 consists of a tergal and a sternal plate; tergosternal fissures appear slightly weaker than those of the following segments, but are clearly present (Figs. 7e, 8c).
A midventral fissure is not present. Tubules are present in subdorsal and ventrolateral positions (Figs. 6a, b, 7b, e, 8b, c), pore fields (gco1) in ventromedial positions (Figs. 6b, 7e), and sensory spots in middorsal, midlateral (Figs. 7b, 8c) and ventromedial positions (Figs. 6b, 7e). Sensory spots on this and all following segments are rounded (Fig. 7b) or wedge-shaped (Fig. 7e) and differ conspicuously in size. Cuticular hairs are bracteate and appear in one anterior row with relatively short hairs, and a more posterior row with longer hairs; all hairs on this the following segments are regular acicular in shape. Both rows stretch over the dorsal and lateral sides, with a short midlateral interruption, and end in the ventromedial position. A few, short filiform cuticular extensions are located in the paraventral areas. A well-developed secondary fringe with minute fringe tips wraps around the anterior part of the segment. Posterior segment margin as on preceding segment.

Segment 3 and following seven segments consist of one tergal and two sternal plates. Segment with sensory spots in subdorsal positions only; sensory spots large and wedgeshaped. Pore fields (gco1) present in ventromedial positions (Figs. 6b, 7e). Cuticular hairs in one anterior row with short hairs, stretching over the tergal plate and into the ventromedial areas of the sternal plates; sternal plates often with a single long hair in addition to the short ones. Additional longer hairs present in a somewhat more diffuse, posterior row, present on the tergal plate only. Paraventral areas with two rather small patches of very short filiform cuticular extensions. Secondary fringe and posterior segment margin as on preceding segment. 
Segment 4 with middorsal spine (Figs. 6a, 7c, 8a, d). Sensory spots not present. Pore fields (gco1) present in ventromedial positions. Pectinate fringe and secondary fringe as on preceding segment. Cuticular hairs also as on preceding segment, but the transverse bands are now also interrupted middorsally.

Segment 5 with lateroventral tubules (Fig. 6b). A pair of rather small and rounded sensory spots present in paradorsal positions (Fig. 7c). Pore fields (gco1) present in ventromedial positions. Cuticular hairs, secondary fringe and pectinate fringe as on preceding segment.

Segment 6 with single middorsal spine (Figs. 6a, 7c, 8a, d), but no lateroventral ones (Figs. 6b, 7a). Large, wedgeshaped sensory spots present in paradorsal and midlateral positions (Figs. 6a, 7c, 8d), and more regular-sized ones in ventromedial positions. Pore fields present in ventromedial positions. Cuticular hairs, secondary fringe and pectinate fringe as on preceding segment.

Segment 7 without spines. Large, wedge-shaped sensory spots present in paradorsal positions, and pore fields (gco1) in ventromedial positions, close to the paraventral area. Cuticular hairs, secondary fringe and pectinate fringe as on preceding segment.

Segment 8 with single middorsal spine (Figs. 6a, 8a), paired lateroventral spines, and paired sublateral tubules (Figs. 6b, 7f, 8e). A pair of small, rounded sensory spots present in paradorsal positions, and pore fields (gco1) in paraventral positions. The two rows of cuticular hairs are more diffuse and appear more like a broad transverse band of hairs, but still with the longest hairs most posteriorly (Fig. 7f). Pectinate fringe and secondary fringe as on preceding segment.

Segment 9 with lateroventral spines (Figs. 6b, 8e). Sensory spots present in paradorsal, midlateral and ventrolateral positions. Paired pore fields (gco1) present in paraventral positions. Rounded sieve plates in sublateral positions (Fig. 8e). Cuticular hairs, secondary fringe and pectinate fringe as on preceding segment; no filiform cuticular extensions in paraventral patches.

Segment 10 without spines, but with laterodorsal tubules (Figs. 6a, 7h). Tubules larger and more developed in males (7 $\mu \mathrm{m})$ (Fig. 6c) than in females $(>4 \mu \mathrm{m})$ (Fig. 6a). Sensory spots present in subdorsal and ventrolateral positions. Pore fields (gco1) could only be identified in paraventral positions, but more could be present. Cuticular hairs mostly scattered in a pair of lateral patches, and around the tergosternal junctions; sternal plates only with one anterior row of very short hairs. Posterior margins of the sternal plates concave. Pectinate fringe well-developed; secondary fringe present, but with smaller fringe tips.

Segment 11 consists of two tergal and two sternal plates (Figs. 6a, 7h). Lateral terminal spines present in both sexes; females in addition with lateral terminal accessory spines (Fig. 6a), and males with three penile spines (Figs. 6c, d, 7h, i). Dorsal and ventral penile spines are tubular, whereas the median one is modified into stout, triangular or cone-shaped structure (Fig. 7h, i). ensory spots present in subdorsal position only. Secondary fringe and cuticular hairs not present, but filiform cuticular extensions present in mid- to subdorsal areas. Tergal extensions are short with interrupted mesial margins; sternal extensions short and rounded (Fig. $7 \mathrm{~g}$ ).

Meristoderes elleae new species, (Figs. 9, 10, 11; Tables 5, 6)

\section{Diagnosis}

Species with segments 1 and 2 consisting of closed rings, segments 3-10 of one tergal and two sternal plates, and segment 11 of two tergal and two sternal plates; segment 2 with very weakly developed fissures in lateroventral positions, indicating a partial differentiation of the segment into one tergal and one sternal plate. Segment 2 with tubules in ventrolateral positions; middorsal spines present on segments 4, 6, and 8; tubules in lateroventral position on segment 5, and spines in same positions on segments 6-9; tubules in laterodorsal position on segment 10. Tubules on segment 10 do not show any particular sexual dimorphism. Glandular cell outlet type 2 present in laterodorsal and sublateral positions on segment 2 , in sublateral positions on segment 6 , and in lateral accessory positions on segment 8 .

\section{Type material}

All examined specimens were collected with a box corer on 6 October 2008. Holotype: Adult female, collected at station MAP-32, in the strait between the Korean mainland and Taema (Kor.)/Tsushima (Jap.) Island in the East Sea, (Fig. 1c), $34^{\circ} 47.19^{\prime} \mathrm{N}, 129^{\circ} 05.58^{\prime} \mathrm{E}$, Korea, from mud with tiny shells at $109 \mathrm{~m}$ depth, mounted in Fluoromount-G, deposited at NIBR under accession number NIBRIV0000465087. Some segments of the holotype are slightly damaged; hence, the habitus illustration in Fig. 9 is partly based on camera lucida drawing of the holotype, and partly on reconstruction from other specimens observed with LM or SEM. Allotype: Adult male, collected at station MAP-29, in the Korea Strait, about $70 \mathrm{~km}$ south of Jeju Island, (Fig. 1c), $32^{\circ} 37.49^{\prime} \mathrm{N}, 126^{\circ} 42.24^{\prime} \mathrm{E}$, Korea, from mud with tiny shells at $118 \mathrm{~m}$ depth, mounted in Fluoromount-G, deposited at NHMD under accession number ZMUC KIN-593. Paratype: one adult male, collected together with holotype, mounted in Fluoromount-G, deposited at NHMD under accession number ZMUC KIN-594. Additional material includes one male specimen mounted for SEM, collected at station MAP28, in the Korea Strait, about midway between the 
easternmost point of Jeju Island and the southern tip of Taema/Tsushima Island, (Fig. 1c), $33^{\circ} 44.51^{\prime} \mathrm{N}, 128^{\circ} 15.39^{\prime} \mathrm{E}$, Korea, from mud with tiny shells at $126 \mathrm{~m}$ depth. The specimen is stored in the personal collection of MVS.

\section{Etymology}

The species is named after the artist and scientific illustrator Stine Elle, who has provided line art illustrations for this and numerous other scientific papers.

\section{Description}

Adult specimens consist of a head, a neck and eleven trunk segments (Figs. 9a, b, 10a). The trunk cuticle appears thin and flexible. Measurements and dimensions (all based on LM) are given in Table 5, and a summary of sensory spot, tubule, spine, and glandular cell outlet positions is provided in Table 6.

The head morphology could not be examined in detail in any of the available specimens. The neck consists of 16 placids, all measuring $11 \mu \mathrm{m}$ in length and $7 \mu \mathrm{m}$ in width at bases, except midventral placid that measures $9 \mu \mathrm{m}$ in width. It was not possible to neither confirm nor reject the presence of trichoscalid plates.

Segment 1 consists of one complete cuticular ring. Pairs of subdorsal and laterodorsal sensory spots present (Fig. 10b, d). Sensory spots are rounded, with numerous papillae and long, marginal cuticular hairs projecting posteriorly. Cuticular hairs otherwise hardly present on the
Fig. 9 Line art illustrations showing general habitus in M. elleae sp. nov. a Female, dorsal view. b Female, ventral view. c Segments 10 and 11 in male, dorsal view. d Segments 10 and 11 in male, ventral view. gco $1 / 2$ glandular cell outlet type $1 / 2, l d$ laterodorsal sensory spot, ldt laterodorsal tubule, ltas lateral terminal accessory spine, lts lateral terminal spine, lvs lateroventral spine, lvt lateroventral tubule, $m d p$ middorsal placid, $m d s$ middorsal spine, $m t j$ midtergal junction, mvp midventral placid, $p d$ paradorsal sensory spot, ps penile spines, $s d$ subdorsal sensory spot, se sternal extension, set seta, te tergal extension, $t s j$ tergosternal junction, $v l t$ ventrolateral tubule, $v m$ ventromedial sensory spot
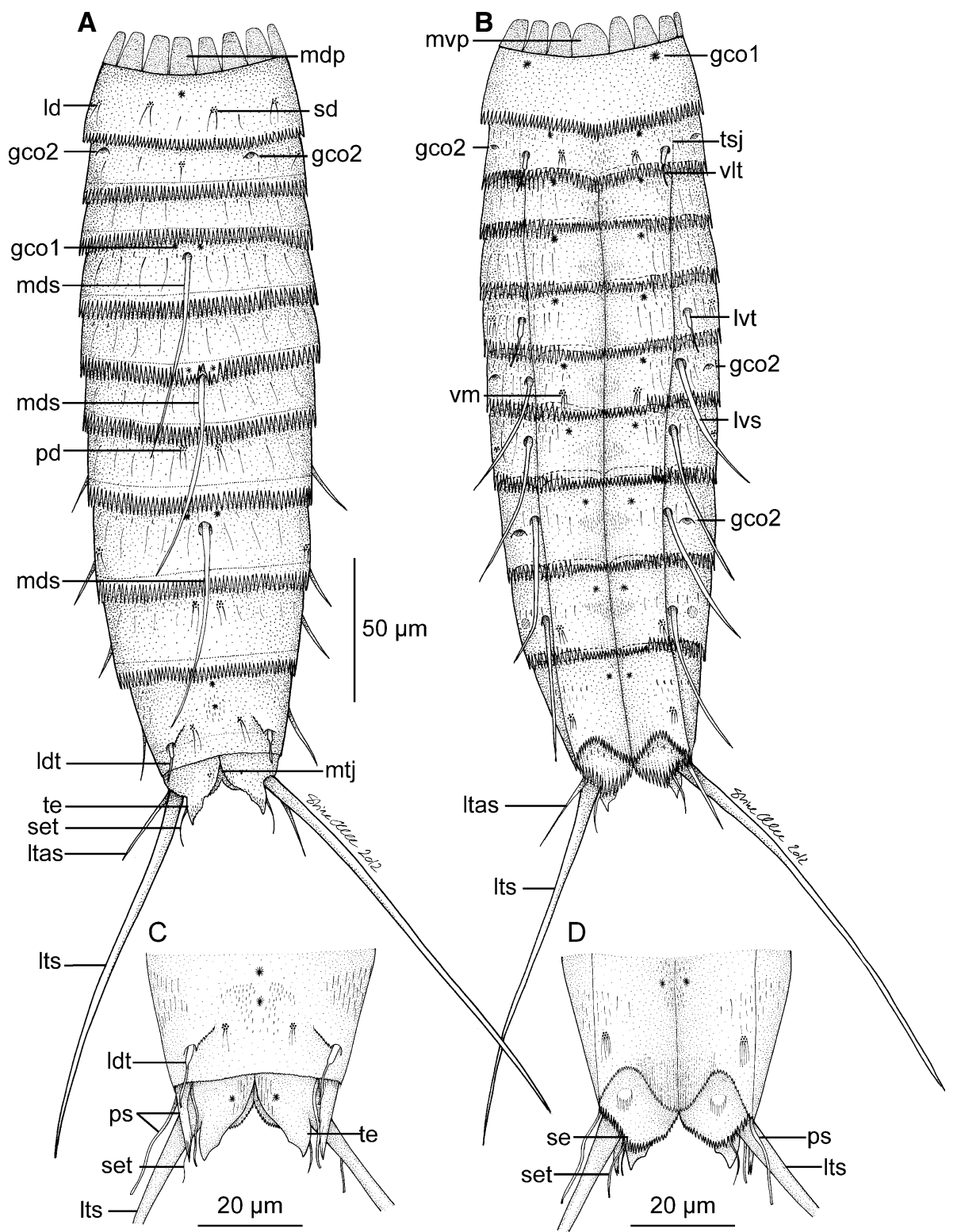


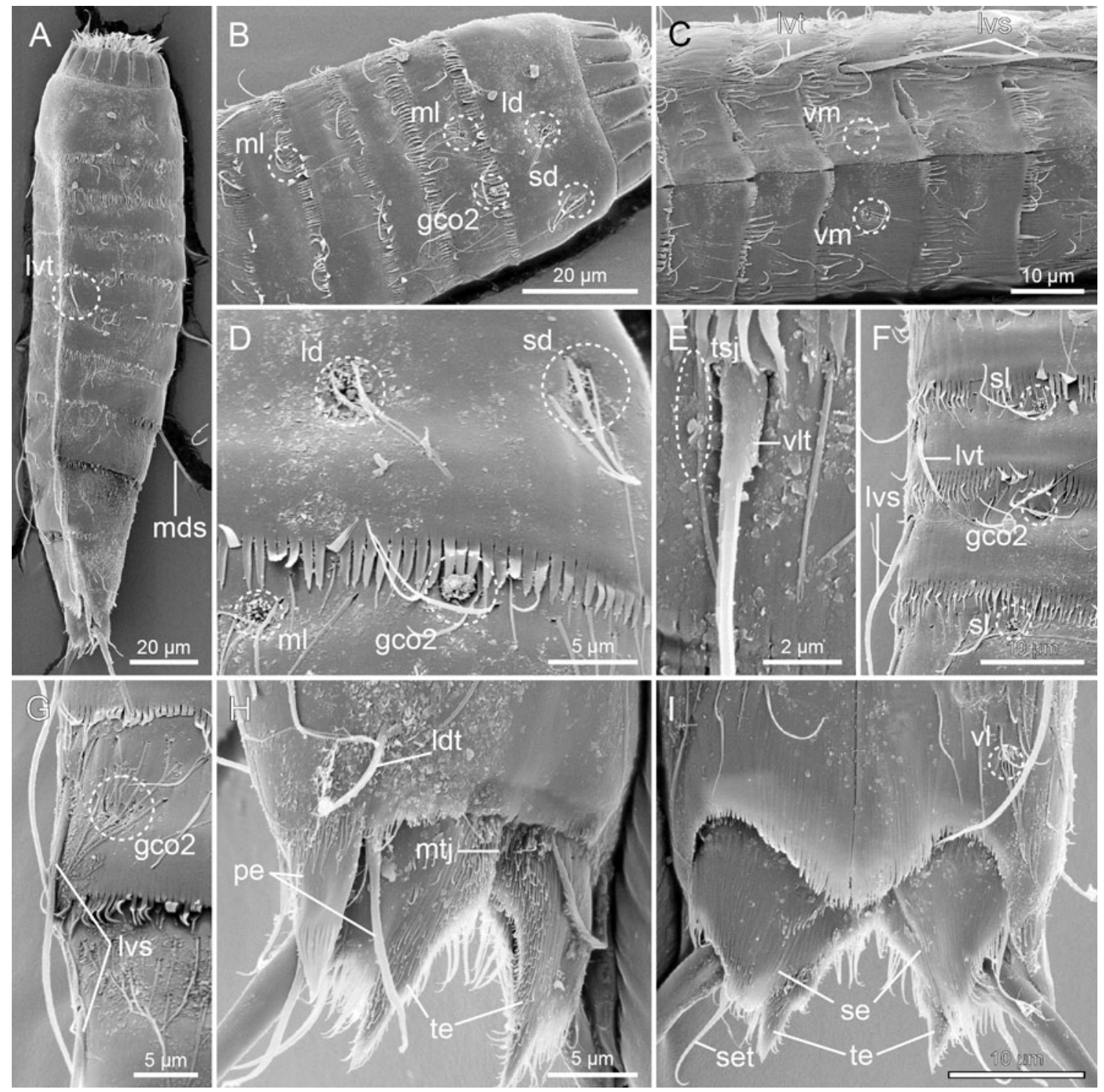

Fig. 10 Scanning electron micrographs showing overviews and details in trunk morphology of male $M$. elleae sp. nov. a Lateral overview of whole specimen. b Segment 1-5, laterodorsal overview. c Segments 4-8, ventral view. d Segments 1 and 2, details in laterodorsal areas. e Segment 2, details around lateroventral and ventrolateral lines. f Segments 4-7, subdorsal and lateroventral areas. g Segments 8 and 9, lateroventral and lateral accessory areas. h Segments 10-11, laterodorsal view. i Segments 10-11, ventral

segment. Glandular cell outlet type 1 (gco1) present as a single, unpaired pore field in middorsal position and as a pair in lateroventral positions. Posterior margin terminates into a regular pectinate fringe that is slightly longer on the ventral half of the segment.

Segment 2 consists of a closed ring, being partly differentiated into a tergal and a sternal plate; tergosternal fissures very weak, appearing as very indistinct lines with SEM (Fig. 10e) and as lateroventral interruptions of the anterior segment pachycyclus with LM (Fig. 11b). A view. gco 2 glandular cell outlet type 2, $l d$ laterodorsal sensory spot, $l d t$ laterodorsal tubule, $l v s$ lateroventral spine, $l v t$ lateroventral tubule, $m d s$ middorsal spine, $m l$ midlateral sensory spot, $m t j$ midtergal junction, pe penile spine, sd subdorsal sensory spot, se sternal extension, set seta, $s l$ sublateral sensory spot, te tergal extension, $t s j$ tergosternal junction, $v l$ ventrolateral sensory spot, $v l t$ ventrolateral tubule, $v m$ ventromedial sensory spot

midventral fissure is not present. Tubules are present in ventrolateral positions (11 $\mu \mathrm{m}$ from SEM) (Fig. 10e), glandular cell outlets type 2 (gco2) in laterodorsal and sublateral positions (Figs. 9a, b, 10b, d, 11a, b), pore fields (gco1) in ventromedial positions, and sensory spots in middorsal, midlateral (Fig. 10b, d) and ventromedial positions. Sensory spots on this and all following segments are rounded, with a tuft of long cuticular hairs projecting posteriorly from the posterior part of the sensory spot. Cuticular hairs are bracteate (as on all following segments) 

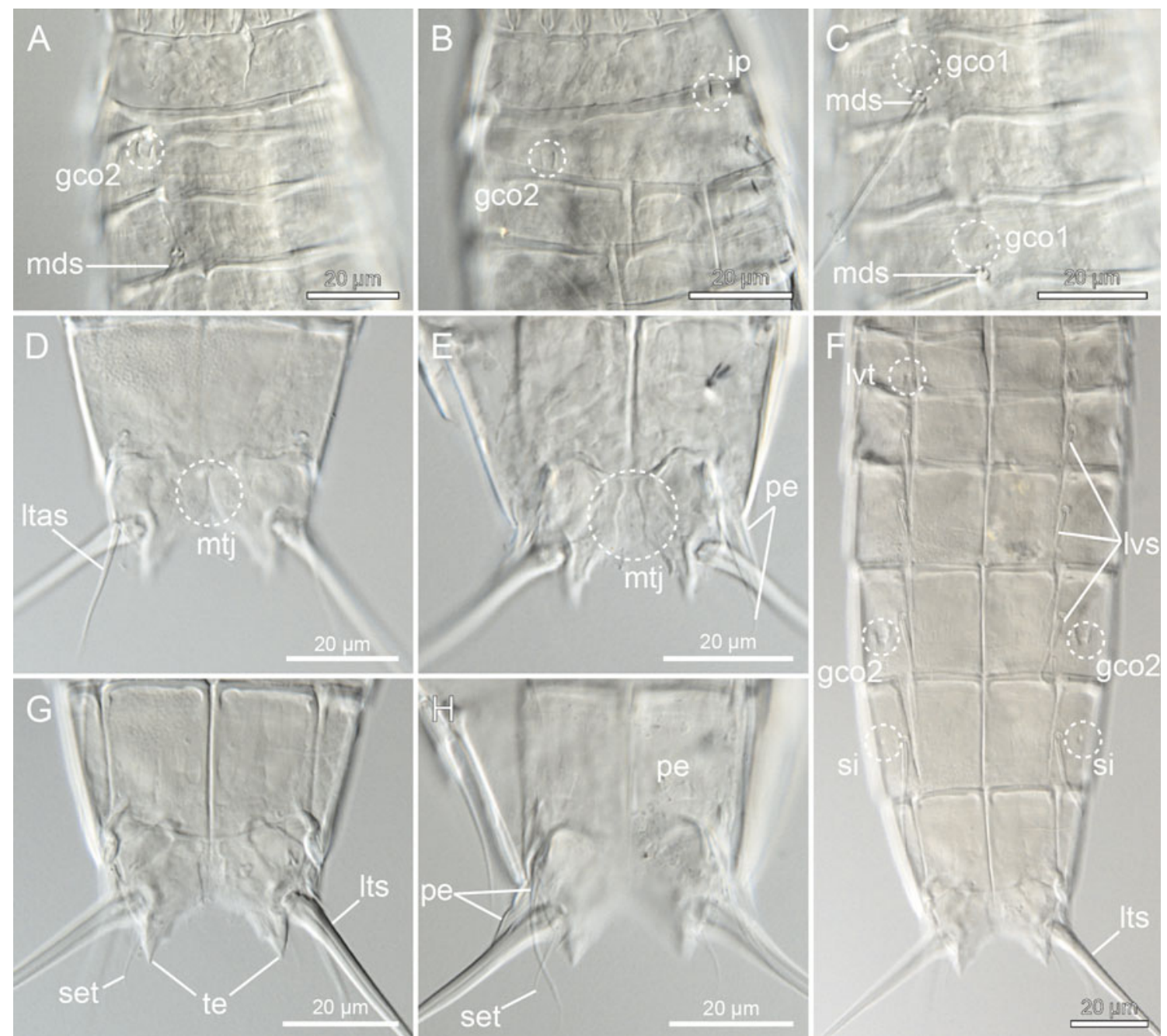

Fig. 11 Light micrographs showing details of neck and trunk morphology in female holotype NIBR Acc. No. NIBRIV0000465087 $(\mathbf{e}, \mathbf{f}, \mathbf{h})$ and male allotype ZMUC KIN-593 (a-d, g) of M. elleae sp. nov. a Segments 1-4, subdorsal view. b Segments 1-4, lateroventral view. c Segments 4-6, dorsal view. d Segments 10-11 in female, dorsal view. e Segments 10-11 in male, focused in between dorsal and ventral plane. f Segments 5-11, ventral view. g Segments 10-11

and appear in one anterior row with relatively short hairs, and a more posterior row with longer hairs; hair pattern on the ventral side is a bit more disorganized, but at least with a small patch of hairs emerging from perforation sites in the midsternal area. Posterior segment margin with thinner fringe tips, compared to preceding segment, and especially the tips on the ventral side appear almost filiform.

Segment 3 and following seven segments consist of one tergal and two sternal plates (Fig. 9b). Pore fields (gco1) present in ventromedial positions, but otherwise no cuticular structures present. Cuticular hairs on tergal plate as on preceding segment; sternal plates with patches of hair emerging from perforation sites in ventromedial and paraventral areas. A weak secondary fringe present on the in female, ventral view. h Segments 10-11 in male, ventral view. gco $1 / 2$ glandular cell outlet type $1 / 2$, ip interruption of pachycyclus in lateroventral position, ltas lateral terminal accessory spine, lts lateral terminal spine, lvs lateroventral spine, lvt lateroventral tubule, $m d s$ middorsal spine, $m t j$ midtergal junction, pe penile spine, set seta, si sieve plate, te tergal extension

anterior part of the segment, partly covered by overlapping preceding segment. Posterior segment margin as on preceding segment.

Segment 4 with middorsal spine (Figs. 9a, 11a, c). Sensory spots apparently not present; however, paradorsal sensory spots could eventually be present on this or one of the following segments, that all are strongly contracted and partly covered by preceding segment. Pore fields (gco1) present in paradorsal (Fig. 11c) and ventromedial positions. A weak secondary fringe present on the anterior part of the segment. Cuticular hairs in paraventral areas replaced by filiform cuticular extensions, hairs otherwise as on preceding segment. Pectinate fringe as on preceding segment. 
Table 5 Measurements of female holotype and paratype of M. elleae sp. nov. from the East Sea and Korea Strait

\begin{tabular}{|c|c|c|c|}
\hline Character & $\begin{array}{l}\text { Length } \\
\text { holotype }\end{array}$ & $\begin{array}{l}\text { Length } \\
\text { allotype }\end{array}$ & $\begin{array}{l}\text { Length } \\
\text { paratype }\end{array}$ \\
\hline TL & $236 \mu \mathrm{m}$ & $206 \mu \mathrm{m}$ & $249 \mu \mathrm{m}$ \\
\hline MSW-7 & $40 \mu \mathrm{m}$ & $37 \mu \mathrm{m}$ & $39 \mu \mathrm{m}$ \\
\hline MSW-7/TL & $16.9 \%$ & $18.0 \%$ & $15.7 \%$ \\
\hline SW-10 & $37 \mu \mathrm{m}$ & $36 \mu \mathrm{m}$ & $37 \mu \mathrm{m}$ \\
\hline SW-10/TL & $15.7 \%$ & $17.15 \%$ & $14.9 \%$ \\
\hline S1 & $27 \mu \mathrm{m}$ & $27 \mu \mathrm{m}$ & $29 \mu \mathrm{m}$ \\
\hline S2 & $25 \mu \mathrm{m}$ & $24 \mu \mathrm{m}$ & $25 \mu \mathrm{m}$ \\
\hline S3 & $24 \mu \mathrm{m}$ & $24 \mu \mathrm{m}$ & $27 \mu \mathrm{m}$ \\
\hline S4 & $25 \mu \mathrm{m}$ & $26 \mu \mathrm{m}$ & $27 \mu \mathrm{m}$ \\
\hline S5 & $26 \mu \mathrm{m}$ & $27 \mu \mathrm{m}$ & $30 \mu \mathrm{m}$ \\
\hline S6 & $28 \mu \mathrm{m}$ & $29 \mu \mathrm{m}$ & $30 \mu \mathrm{m}$ \\
\hline S7 & $29 \mu \mathrm{m}$ & $30 \mu \mathrm{m}$ & $32 \mu \mathrm{m}$ \\
\hline S8 & $32 \mu \mathrm{m}$ & $31 \mu \mathrm{m}$ & $31 \mu \mathrm{m}$ \\
\hline S9 & $33 \mu \mathrm{m}$ & $32 \mu \mathrm{m}$ & $35 \mu \mathrm{m}$ \\
\hline S10 & $31 \mu \mathrm{m}$ & $32 \mu \mathrm{m}$ & $35 \mu \mathrm{m}$ \\
\hline S11 & $29 \mu \mathrm{m}$ & $25 \mu \mathrm{m}$ & $28 \mu \mathrm{m}$ \\
\hline MD4 (ac) & Broken & $54 \mu \mathrm{m}$ & Broken \\
\hline MD6 (ac) & $73 \mu \mathrm{m}$ & Broken & Broken \\
\hline MD8 (ac) & Broken & Broken & $63 \mu \mathrm{m}$ \\
\hline LV6 (ac) & $24 \mu \mathrm{m}$ & $28 \mu \mathrm{m}$ & Broken \\
\hline LV7 (ac) & $30 \mu \mathrm{m}$ & $33 \mu \mathrm{m}$ & Broken \\
\hline LV8 (ac) & $31 \mu \mathrm{m}$ & $37 \mu \mathrm{m}$ & $42 \mu \mathrm{m}$ \\
\hline LV9 (ac) & $37 \mu \mathrm{m}$ & Broken & $44 \mu \mathrm{m}$ \\
\hline LTS & $115 \mu \mathrm{m}$ & $117 \mathrm{~mm}$ & $119 \mu \mathrm{m}$ \\
\hline LTS/TL & $49.0 \%$ & $56.8 \%$ & $47.8 \%$ \\
\hline LTAS (f) & $31 \mu \mathrm{m}$ & N/A & N/A \\
\hline
\end{tabular}

$a c$ acicular spine, $f$ female condition of sexual dimorphic character, LTAS lateral terminal accessory spine, LTS lateral terminal spine, $L V$ lateroventral, $M D$ middorsal, $M S W-7$ Maximum sternal width, measured on segment 7 in this species, $S$ segment lengths, $S W-10$ standard width, always measured on segment $10, T L$ trunk length

Segment 5 with lateroventral tubules $(13 \mu \mathrm{m}$ from SEM) (Figs. 9b, 10a, c, f, 11f). Sensory spots present in sublateral positions (Fig. 10f) and pore fields (gco1) in ventromedial positions. Cuticular hairs, pectinate fringe and secondary fringe as on preceding segment.

Segment 6 with single middorsal (Fig. 9a) and paired lateroventral spines (Figs. 9b, 10c, 11f). Sensory spots present in ventromedial positions (Fig. 10c) and pore fields (gco1) in paradorsal (Fig. 11c) and ventromedial positions. Glandular cell outlets type 2 (gco2) present in sublateral positions (Figs. 9b, 10f). Cuticular hairs, pectinate fringe and secondary fringe as on preceding segment.

Segment 7 with lateroventral spines (Figs. 9b, 10c, 11f). Sensory spots present in paradorsal and sublateral (Fig. 10f) positions, and pore fields (gcol) in ventromedial positions, close to the paraventral area. Cuticular hairs, pectinate fringe and secondary fringe as on preceding segment.

Segment 8 with single middorsal (Fig. 9a) and paired lateroventral spines (Figs. 9b, 11f). Glandular cell outlets type 2 (gco2) present in lateral accessory positions (Figs. 9b, 10g, 11f), and pore fields (gco1) in paradorsal and paraventral positions. Sensory spots not present on this segment. Cuticular hairs, pectinate fringe and secondary fringe as on preceding segment.

Segment 9 with lateroventral spines (Figs. 9b, 10g, 11f). Sensory spots present in paradorsal, midlateral and ventrolateral positions. Paired pore fields (gcol) present in paraventral positions. Sieve plates present in lateral accessory positions, appearing distinct with LM (Fig. 11f) but could not be identified with SEM. Distribution of cuticular hairs slightly more diffuse. Filiform cuticular extensions not present in paraventral patches. Secondary fringe and pectinate fringe as on preceding segment.

Segment 10 without spines, but with laterodorsal tubules (ca. $11 \mu \mathrm{m}$, SEM) (Figs. 9a, c, 10h). No conspicuous sexual dimorphism in tubule length. Sensory spots present in subdorsal and ventrolateral positions. Two unpaired, middorsal pore fields (gcol) and paired paraventral ones present. Cuticular hairs mostly scattered in a pair of lateral patches, and around the tergosternal junctions. Posterior margins of the sternal plates concave. Pectinate fringe well-developed; secondary fringe as on preceding segment.

Segment 11 consists of two tergal and two sternal plates (Figs. 9a, c, 10h, 11d, e). Lateral terminal spines present in both sexes; females in addition with rather short and thin lateral terminal accessory spines (Figs. 9a, b, 11d), and males with three penile spines (Figs. 9c, d, 10h, 11e, h). Dorsal and ventral penile spines appear regular tubular (14 $\mu \mathrm{m}$ and $16 \mathrm{~mm}$ respectively), whereas the median spine is strongly modified into a stout, triangular or coneshaped structure $(10 \mu \mathrm{m}$ long and $4 \mu \mathrm{m}$ broad at base, SEM), with distal wrinkles (Fig. 10h). Sensory spots present in subdorsal position. Secondary fringe and cuticular hairs not present, but filiform cuticular extensions present in mid- and paradorsal areas, and on the sternal plates. Tergal extensions are short with interrupted mesial margins (Figs. 10h, 11g); sternal extensions short and triangular, with fringed margins forming a setal extension from each plate (Figs. 10i, 11g, h).

Meristoderes glaber new species, (Figs. 12, 13; Table 7)

\section{Diagnosis}

Species with segment 1 consisting of a closed ring, segment 2 consisting of a tergal and a sternal plate and welldeveloped tergosternal fissures, segments 3-10 of one 
Table 6 Summary of nature and location of sensory spots, glandular cell outlets, tubules and spines arranged by series in M. elleae sp. nov. from the East Sea and Korea Strait

\begin{tabular}{|c|c|c|c|c|c|c|c|c|c|c|c|}
\hline $\begin{array}{l}\text { Position } \\
\text { segment }\end{array}$ & $\mathrm{MD}$ & PD & SD & LD & ML & SL & LA & LV & VL & VM & PV \\
\hline 1 & gco1 & & ss & ss & & & & gco1 & & & \\
\hline 2 & ss & & & gco2 & ss & gco2 & & & tu & gco 1 , ss & \\
\hline 3 & & & & & & & & & & gco1 & \\
\hline 4 & ac & gco1 & & & & & & & & gco1 & \\
\hline 5 & & & & & & ss & & tu & & gco1 & \\
\hline 6 & ac & gco1 & & & & gco2 & & $\mathrm{ac}$ & & ss, gco1 & \\
\hline 7 & & ss & & & & ss & & $\mathrm{ac}$ & & gco1 & \\
\hline 8 & ac & gco1 & & & & & gco2 & $\mathrm{ac}$ & & & gcol \\
\hline 9 & & ss & & & ss & & si & $\mathrm{ac}$ & ss & & gco1 \\
\hline 10 & gco1, gco1 & & ss & tu & & & & & ss & & gcol \\
\hline 11 & & & ss & & & & ltas (f) & lts & & & \\
\hline
\end{tabular}

$L A$ lateral accessory, $L D$ laterodorsal, $L V$ lateroventral, $M D$ middorsal, $M L$ midlateral, $P D$ paradorsal, $P V$ paraventral, $S D$ subdorsal, $S L$ sublateral, $V L$ ventrolateral, $V M$ ventromedial, $a c$ acicular spine, $f$ female condition of sexual dimorphic character, $g c o l / 2$ glandular cell outlet type I or II, ltas lateral terminal accessory spine, lts lateral terminal spine, si sieve plate, ss sensory spot, $t u$ tubule

tergal and two sternal plates, and segment 11 of two tergal and two sternal plates. Segment 2 with tubules in subdorsal and ventrolateral positions; middorsal spines present on segments 4, 6 and 8; tubules in lateroventral position on segment 5 , spines in lateral accessory positions on segment 7 , and in lateroventral positions on segments 8 and 9; tubules in laterodorsal position on segment 10 . Tubules on segment 10 show some sexual dimorphism, being slightly larger in males than in females. Glandular cell outlet type 2 present in sublateral position on segment 8. Perforation sites present on trunk, but cuticular hairs reduced to very minute scales.

\section{Type material}

Holotype Adult female (Fig. 13a), collected on 17 November 2004 at station CYC-34, near Deogjeok Island, in the Korean West Sea, a little southwest of Incheon, (Fig. 1d), $37^{\circ} 13.15^{\prime} \mathrm{N}, 126^{\circ} 08.33^{\prime} \mathrm{E}$, from subtidal sand at $30 \mathrm{~m}$ depth, mounted for SEM.

Allotype Adult male, same data as holotype, mounted for SEM at same stub as holotype.

Paratypes One adult male, four adult females, two specimens of uncertain gender, same data as holotype, mounted for SEM at same stub as holotype. All types are deposited at NIBR under accession number NIBRIV0000465088.

\section{Etymology}

The species name "glaber" meaning "hairless" in Latin refers to the special condition of the species' cuticular hairs that are reduced to minute scales.

\section{Description}

Adult specimens consist of a head, a neck and eleven trunk segments (trunk length ca. 195-235 $\mu \mathrm{m}$, SEM) (Figs. 12a, b, 13a). The description is solely based on specimens mounted for SEM, and reliable measures made with LM were not available. Approximate measures, estimated from SEM photographs, are provided in the descriptions below. A summary of sensory spot, tubule, spine, and glandular cell outlet positions is provided in Table 7. Due to the condition of the specimens, it was often difficult to confirm the presence of pore fields (gco1); hence, if pore fields are not mentioned in the description, it does not necessarily confirm the absence of the structure.

The head morphology could not be examined in detail in any of the available specimens. The neck consists of 16 placids, all measuring $9 \mu \mathrm{m}$ in length and $5 \mu \mathrm{m}$ in width at bases (Fig. 13b), except midventral placid (Fig. 13c) that measures $8 \mu \mathrm{m}$ in width. Placids in positions corresponding to introvert sections 2 and 10 with broad trichoscalid plates; smaller, elongate trichoscalid plates associated with placids in positions corresponding to introvert sections 4, 5, 7 and 8 .

Segment $1(22 \mu \mathrm{m})$ consists of one complete cuticular ring. Pairs of subdorsal, laterodorsal and ventrolateral sensory spots present (Figs. 12a, b, 13b, c). Sensory spots are rounded, rather small and without marginal hairs. Glandular cell outlet type 1 (gco1) present as a single, unpaired pore field in middorsal position (Fig. 13b) and as a pair in lateroventral positions. Cuticular hairs or perforation sites not present. Posterior segment margin with midventral, convex extension (Fig. 13c); pectinate fringe hardly visible. 
Fig. 12 Line art illustrations showing general habitus in M. glaber sp. nov. a Female, dorsal view. b Female, ventral view. gco 2 glandular cell outlet type 2, las lateral accessory spine, $l d$ laterodorsal sensory spot, ldt laterodorsal tubule, ltas lateral terminal accessory spine, lts lateral terminal spine, lvs lateroventral spine, lvt lateroventral tubule, $m d p$ middorsal placid, $m d$ middorsal sensory spot, $m d s$ middorsal spine, $m t j$ midtergal junction, mvp midventral placid, $p d$ paradorsal sensory spot, $s d t$ subdorsal sensory spot, te tergal extension, tsj tergosternal junction, $v l t$ ventrolateral tubule

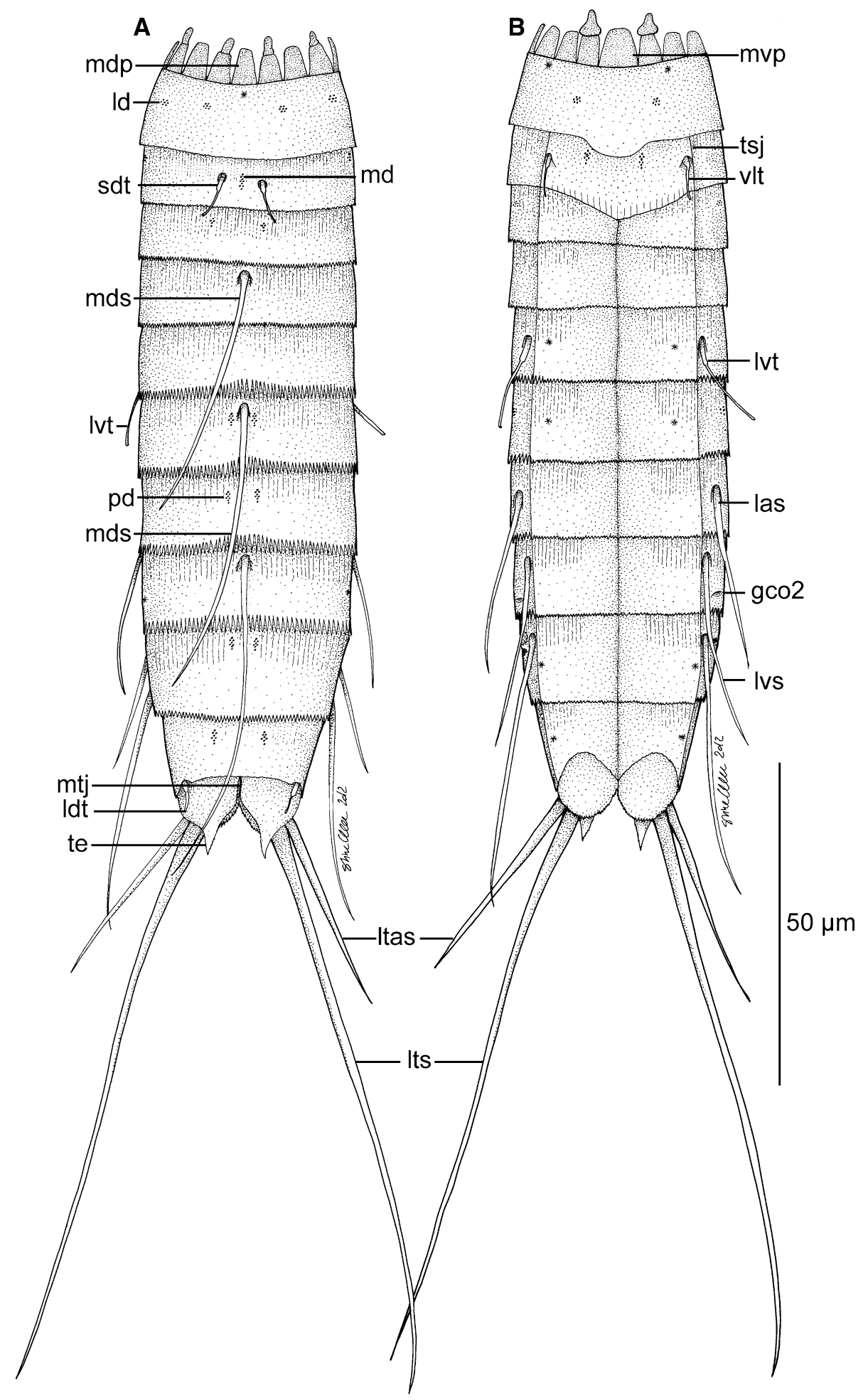

Segment $2(18 \mu \mathrm{m})$ consists of a tergal and a sternal plate (Figs. 12b, 13c); tergosternal fissures very distinct. Tubules are present in subdorsal $(16 \mu \mathrm{m})$ (Figs. 12a, 13b) and ventrolateral $(15 \mu \mathrm{m})$ (Figs. 12b, 13c) positions, and sensory spots in middorsal (Fig. 13b), midlateral and ventromedial (Fig. 13c) positions. Middorsal and ventromedial sensory spots large and wedge-shaped; midlateral ones small and rounded. Perforation sites are distributed around the segment, but cuticular hairs are reduced to minute scales (see Fig. 13g for corresponding hairs on 


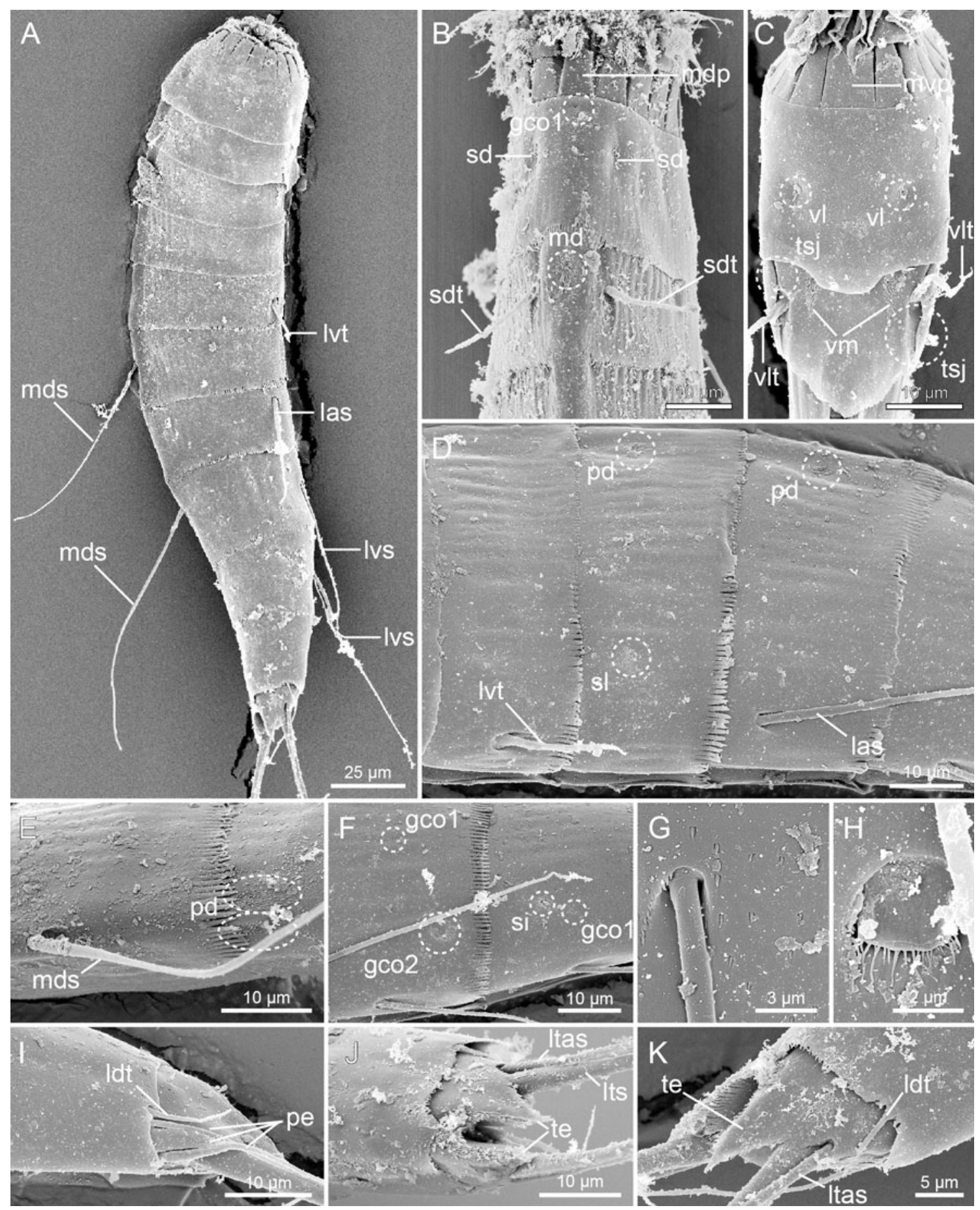

Fig. 13 Scanning electron micrographs showing overviews and details in trunk morphology in female holotype NIBR Acc. No. NIBRIV0000465088 (a, e, j, k), male allotype ZMUC KIN-593 (d, f-i), and paratypes $(\mathbf{b}, \mathbf{c})$ of $M$. glaber sp. nov. a Lateral overview of whole specimen. b Neck region and segments 1 and 2, dorsal view. c Neck region and segments 1 and 2, ventral view. d Segments 5-7, lateral view. e Segments 8 and 9, dorsal view. f Segments 8 and 9, lateral view. $\mathbf{g}$ Detail showing attachment site of lateral accessory spine on segment 7 and perforation sites with minute, scale-like hair. h Detail showing sublateral glandular cell outlet type 2 on segment 8 . i Segments $10-11$ in male, lateral view. j Segments $10-11$ in female, dorsal view. k Segments $10-11$ in female, lateral view. gco $1 / 2$ glandular cell outlet type $1 / 2$, las lateral accessory spine, $l d t$ laterodorsal tubule, ltas lateral terminal accessory spine, lts lateral terminal spine, lvs lateroventral spine, lvt lateroventral tubule, $m d$ middorsal sensory spot, $m d p$ middorsal placid, $m d s$ middorsal spine, $m v p$ midventral placid, $p d$ paradorsal sensory spot, $p e$ penile spine, $s d$ subdorsal sensory spot, $s d t$ subdorsal tubule, si sieve plate, $s l$ sublateral sensory spot, $t e$ tergal extension, $t s j$ tergosternal junction, $v l$ ventrolateral sensory spot, $v l t$ ventrolateral tubule, $v m$ ventromedial sensory spot 
Table 7 Summary of nature and location of sensory spots, glandular cell outlets, tubules and spines arranged by series in M. glaber sp. nov. from the West Sea

\begin{tabular}{|c|c|c|c|c|c|c|c|c|c|c|}
\hline $\begin{array}{l}\text { Position } \\
\text { segment }\end{array}$ & MD & PD & SD & LD & ML & SL & LA & LV & VL & VM \\
\hline 1 & gco1 & & ss & ss & & & & gco1 & ss & \\
\hline 2 & ss & & tu & & ss & & & & tu & ss \\
\hline 3 & & & ss & & & ss & & & & \\
\hline 4 & ac & & & & & & & & & \\
\hline 5 & & & & & & & & tu & & ss \\
\hline 6 & $\mathrm{ac}$ & Ss & & & & Ss & & & & ss \\
\hline 7 & & ss & & & & & $\mathrm{ac}$ & & & \\
\hline 8 & ac & & & & gco1 & gco2 & & $\mathrm{ac}$ & & \\
\hline 9 & & ss & & & & gcol, si & & $\mathrm{ac}$ & ss & \\
\hline 10 & & & Ss & tu & & & & & ss & \\
\hline 11 & & & & & & & ltas (f) & lts & & \\
\hline
\end{tabular}

$L A$ lateral accessory, $L D$ laterodorsal, $L V$ lateroventral, $M D$ middorsal, $M L$ midlateral, $P D$ paradorsal, $S D$ subdorsal, $S L$ sublateral, $V L$ ventrolateral, $V M$ ventromedial, $a c$ acicular spine, $f$ female condition of sexual dimorphic character, gcol/2 glandular cell outlet type I or II, ltas lateral terminal accessory spine, lts lateral terminal spine, si sieve plate, $s s$ sensory spot, $t u$ tubule

segment 7). Posterior segment margin with minute fringe tips.

Segment $3(23 \mu \mathrm{m})$ and following seven segments consist of one tergal and two sternal plates (Fig. 12b). Rounded sensory spots present in subdorsal and sublateral positions. A weak secondary fringe is present on the anterior part of the segment, partly covered by overlapping preceding segment. Perforation sites and posterior segment margin as on preceding segment.

Segment $4(25 \mu \mathrm{m})$ with middorsal spine $(57 \mu \mathrm{m})$ (Fig. 12a). Otherwise no significant cuticular structures present. Perforation sites and secondary fringe as on preceding segment. Posterior segment margin with better developed pectinate fringe.

Segment $5(25 \mu \mathrm{m})$ with lateroventral tubules $(22 \mu \mathrm{m})$ (Figs. 12b, 13a, d). Rounded sensory spots present in ventromedial positions, but rather close to the ventrolateral line. Perforation sites, secondary fringe and posterior segment margin as on preceding segment.

Segment $6(28 \mu \mathrm{m})$ with single middorsal spine $(70 \mu \mathrm{m})$ (Figs. 12a, 13a). Sensory spots present in paradorsal (Fig. 13d), sublateral and ventromedial positions, the latter near the ventrolateral lines. Paradorsal sensory spots wedge-shaped; sublateral and ventromedial ones rounded. Perforation sites, secondary fringe and posterior segment margin as on preceding segment.

Segment $7(30 \mu \mathrm{m})$ with lateral accessory spines $(65 \mu \mathrm{m})$ (Figs. 12b, 13d). Wedge-shaped sensory spots present in paradorsal positions. Perforation sites, secondary fringe and posterior segment margin as on preceding segment.

Segment $8(35 \mu \mathrm{m})$ with single middorsal spine $(88 \mu \mathrm{m})$ (Figs. 12a, 13a, e) and paired lateroventral $(56 \mu \mathrm{m})$ spines
(Figs. 12b, 13a, f). Glandular cell outlets type 2 (gco2) present in lateral accessory positions (Fig. 13f, h), and pore fields (gco1) in midlateral positions (Fig. 13f). Sensory spots not present on this segment. Perforation sites and secondary fringe as on preceding segment; fringe tips on posterior segment margin larger.

Segment $9(35 \mu \mathrm{m})$ with lateroventral spines $(74 \mu \mathrm{m})$ (Figs. 12b, 13a, f). Rounded sensory spots present in paradorsal (Fig. 13e) and ventrolateral positions. A pair of tiny sieve plates present in sublateral positions (Fig. 13f). Paired pore fields (gco1) present just posterior to the sieve plates (Fig. 13f). Perforation sites, secondary fringe and posterior segment margin as on preceding segment.

Segment $10(31 \mu \mathrm{m})$ without spines, but with laterodorsal tubules (Figs 12a, 13i, k); tubules in females (Fig. 13k) shorter $(6 \mu \mathrm{m})$ than those in males (Fig. 13i) $(11 \mu \mathrm{m})$. Sensory spots present in subdorsal and ventrolateral positions. Perforation sites restricted to lateral sides of segment. Secondary fringe not present. Posterior segment margin with rather weak pectinate fringe.

Segment $11(24 \mu \mathrm{m})$ consists of two tergal and two sternal plates (Figs. 12a, 13j). Lateral terminal spines $(150 \mu \mathrm{m})$ present in both sexes; females in addition with lateral terminal accessory spines $(51 \mu \mathrm{m})$ (Figs. 12a, b, 13j, k), and males with three penile spines (Fig. 13i). Dorsal and ventral penile spines rather long and regular tubular ( $28 \mu \mathrm{m}$ and $30 \mathrm{~mm}$ respectively), whereas the median spine is strongly modified into a very stout, triangular or cone-shaped structure $(9 \mu \mathrm{m}$ long and $3 \mu \mathrm{m}$ broad at base, SEM), with distal wrinkles (Fig. 13i). Sensory spots not present. Secondary fringe and perforation sites not present. Tergal extensions triangular (Fig. 13i, k); sternal extensions short and rounded. 

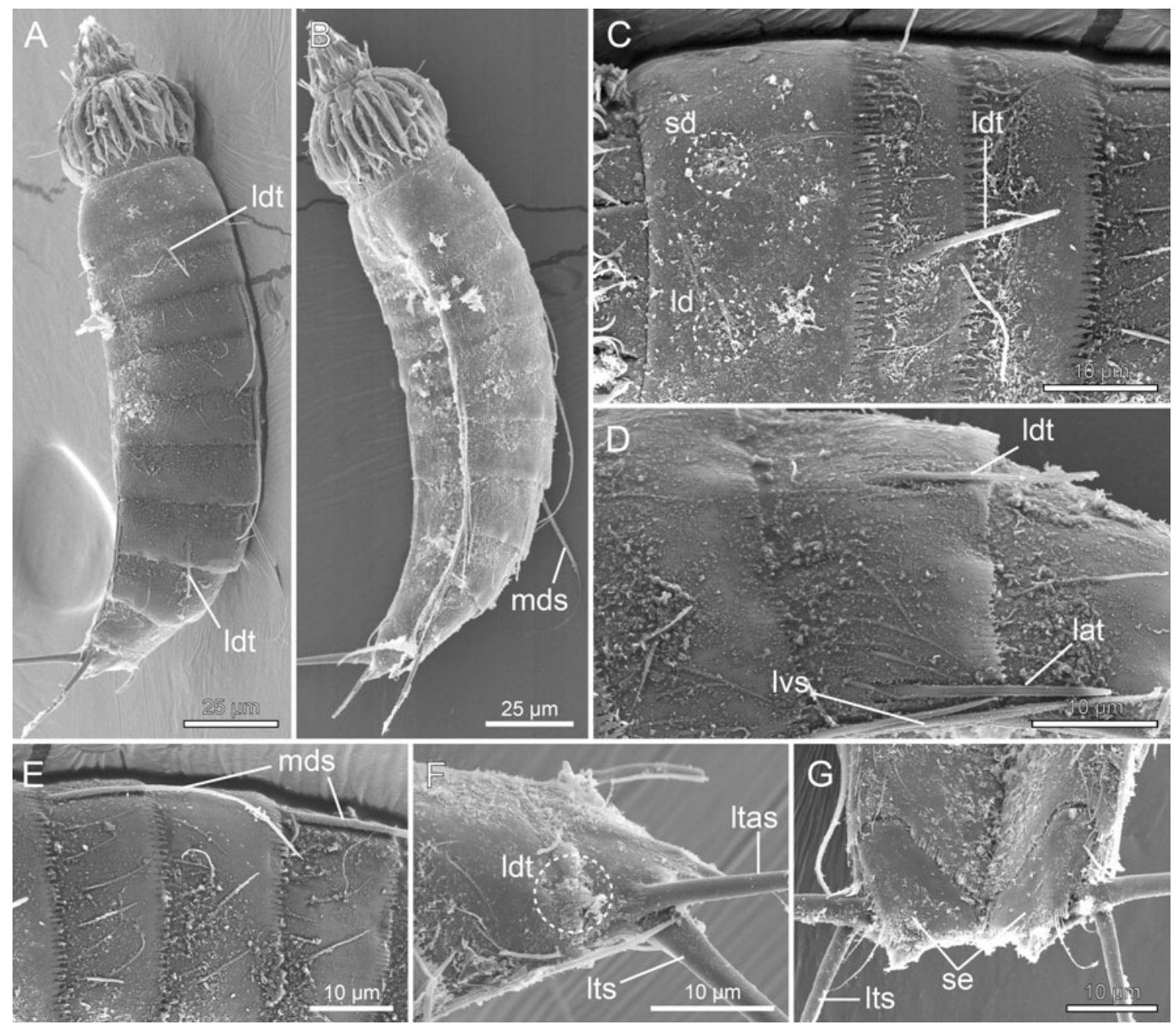

Fig. 14 Scanning electron micrographs showing overviews and details in trunk morphology in female Meristoderes sp. from Station MAP-32, Korean East Sea. a Laterodorsal overview of whole specimen. b Lateroventral overview of whole specimen. c Middorsal to laterodorsal areas of segments 1 and 2. d Segments 7-8, lateral view. e Middorsal to laterodorsal areas of segments 4-6. f Segments

\section{Meristoderes sp., (Fig. 14)}

A fifth new species of Meristoderes was recorded from the examined samples. Unfortunately, only one specimen was available, and even though its spine/tubule pattern is unique and clearly indicates that it represents a new species, we find it too premature to make a formal description, solely based on this single specimen. Instead, we will provide a detailed morphological account, which will make it possible to determine whether specimens collected in future studies are conspecific with our specimen.

\section{Diagnosis}

Species with segments 1 and 2 consisting of closed rings, and segments $3-11$ of one tergal and two sternal plates;
10 and 11, laterodorsal view. $\mathrm{g}$ Segments 10 and 11, ventral view. lat lateral accessory tubule, $l d$ laterodorsal sensory spot, ldt laterodorsal tubule, ltas lateral terminal accessory spine, lts lateral terminal spine, lvs lateroventral spine, $m d s$ middorsal spine, $s d$ subdorsal sensory spot, se sternal extension

segment 2 with very weakly developed fissures in lateroventral positions, indicating the partial differentiation of one tergal and one sternal plate. Segment 2 with tubules in laterodorsal and ventrolateral positions; middorsal spines present on segments 4,6 and 8 ; tubules in lateroventral position on segment 5 , and spines in same positions on segments 6-9; tubules in laterodorsal and lateral accessory positions on segment 8 , and in laterodorsal positions on segment 10 . Tubules on segment 10 are very short in female; male condition not known.

\section{Examined material}

A single female specimen, collected on 6 October 2008 at station MAP-32, in the strait between the Korean mainland and Taema (Kor.)/Tsushima (Jap.) Island in the East Sea, 
Table 8 Summary of nature and location of sensory spots, glandular cell outlets, tubules and spines arranged by series in Meristoderes sp. from station MAP-32 in the East Sea

\begin{tabular}{|c|c|c|c|c|c|c|c|c|}
\hline $\begin{array}{l}\text { Position } \\
\text { segment }\end{array}$ & MD & SD & LD & ML & LA & LV & VL & VM \\
\hline 1 & gco1 & Ss & ss & & & & & ss \\
\hline 2 & & & tu & ss & & & $\mathrm{tu}$ & ss \\
\hline \multicolumn{9}{|l|}{3} \\
\hline 4 & $\mathrm{ac}$ & & & & & & & \\
\hline 5 & & & & & & tu & & ss \\
\hline 6 & $\mathrm{ac}$ & & & & & $\mathrm{ac}$ & & ss \\
\hline 7 & & & & & & $\mathrm{ac}$ & & \\
\hline 8 & $\mathrm{ac}$ & & tu & & tu & $\mathrm{ac}$ & & \\
\hline 9 & & & & & & $\mathrm{ac}$ & & \\
\hline 10 & & & tu & & & & Ss & \\
\hline 11 & & & & & ltas & lts & & \\
\hline
\end{tabular}

$L A$ lateral accessory, $L D$ laterodorsal, $L V$ lateroventral, $M D$ middorsal, $M L$ midlateral, $S D$ subdorsal, $V L$ ventrolateral, $V M$ ventromedial, $a c$ acicular spine, gcol glandular cell outlet type I, ltas lateral terminal accessory spine, lts lateral terminal spine, $s s$ sensory spot, tu tubule

$34^{\circ} 47.19^{\prime} \mathrm{N}, 129^{\circ} 05.58^{\prime} \mathrm{E}$, Korea, from mud with tiny shells at $109 \mathrm{~m}$ depth. This locality is also type locality for $M$. elleae sp. nov. (see Fig. 1c).

\section{Description}

The adult specimen consists of a head, a neck and eleven trunk segments (Fig. 14a, b). The trunk cuticle appears relatively hard. The collected female was mounted for SEM and is stored in the personal collection of MVS. Only a few measures could be estimated from the SEM examinations. These are provided with the following description. A summary of sensory spot, tubule, spine, and glandular cell outlet positions is provided in Table 8. Due to the condition of the specimen, it was not always possible to confirm the presence of pore fields (gco1) and sensory spots; hence, if these structures are not mentioned in the description, it does not necessarily confirm the absence of the structures.

The head morphology could not be examined in detail in the available specimen. The neck consists of 16 placids, all measuring $10 \mu \mathrm{m}$ in length and $6 \mu \mathrm{m}$ in width at bases, except midventral placid that measures $9 \mu \mathrm{m}$ in width. Placids in positions corresponding to introvert sections 2 and 10 with broad trichoscalid plates; smaller, elongate trichoscalid plates associated with placids in positions corresponding to introvert sections 4, 5, 7 and 8 .

Segment $1(21 \mu \mathrm{m})$ consists of one complete cuticular ring. Pairs of subdorsal, laterodorsal (Fig. 14c) and ventromedial sensory spots present. Sensory spots are rounded, with marginal hairs. Cuticular hairs or perforation sites otherwise not present in this segment. Glandular cell outlet type 1 (gco1) present as a single, unpaired pore field in middorsal position. Posterior segment margin straight, with a regular pectinate fringe.
Segment $2(16 \mu \mathrm{m})$ consists of a closed ring, being partly differentiated into a tergal and a sternal plate; tergosternal fissures very weak, appearing as very indistinct lines in SEM. A midventral fissure is not present. Tubules are present in laterodorsal $(16 \mu \mathrm{m})$ (Fig. 14a, c) and ventrolateral $(17 \mu \mathrm{m})$ positions, and sensory spots at least in midlateral and ventromedial positions. Cuticular hairs appear in a band around the anterior part of the segment. Posterior segment margin as on preceding segment.

Segment $3(16 \mu \mathrm{m})$ and all following segments consist of one tergal and two sternal plates. No significant cuticular structures noted. Cuticular hair and posterior segment margin as on preceding segment.

Segment $4(20 \mu \mathrm{m})$ with middorsal spine $(35 \mu \mathrm{m})$ (Fig. 14a, e). Otherwise no significant cuticular structures visible. Cuticular hair and posterior segment margin as on preceding segment.

Segment $5(20 \mu \mathrm{m})$ with lateroventral tubules $(16 \mu \mathrm{m})$. Rounded sensory spots present in ventromedial positions. Cuticular hair and posterior segment margin as on preceding segment.

Segment $6(20 \mu \mathrm{m})$ with single middorsal spine $(47 \mu \mathrm{m})$ (Fig. 14a, e) and paired lateroventral $(26 \mu \mathrm{m})$ spines. Sensory spots present in ventromedial positions. Cuticular hair and posterior segment margin as on preceding segment.

Segment $7(24 \mu \mathrm{m})$ with lateroventral $(30 \mu \mathrm{m})$ spines. Otherwise, no cuticular structures were observed. Cuticular hair and posterior segment margin as on preceding segment.

Segment $8(25 \mu \mathrm{m})$ with single middorsal $(50 \mu \mathrm{m})$ (Fig. 14a) and paired lateroventral $(32 \mu \mathrm{m})$ spines (Fig. 14d). Tubules are in addition present in laterodorsal $(19 \mu \mathrm{m})$ and lateral accessory $(20 \mu \mathrm{m})$ positions (Fig. 14d). Cuticular hair and posterior segment margin as on preceding segment. 
Segment $9(23 \mu \mathrm{m})$ with lateroventral spines $(35 \mu \mathrm{m})$. Otherwise, no cuticular structures were observed. Cuticular hair and posterior segment margin as on preceding segment.

Segment $10(23 \mu \mathrm{m})$ without spines, but with laterodorsal tubules; tubules in the single, available female specimen are rather short $(5 \mu \mathrm{m})$ (Fig. 14f). Sensory spots present at least in ventrolateral positions. Perforation sites restricted to lateral sides of segment. Posterior segment with pectinate fringe, and deep ventrolateral incisions (Fig. 14g).

Segment $11(21 \mu \mathrm{m})$ with lateral terminal spines $(65 \mu \mathrm{m})$ and lateral terminal accessory spines $(33 \mu \mathrm{m})$, at least in females (Fig. 14f, g). Male morphology not known. Sensory spots not present. Tergal extensions triangular; sternal extensions broadly rounded, with fringed margins and a few fringes extended into setae (Fig. 14g).

\section{Discussion}

\section{Diagnostic characters in species of Meristoderes}

With six formally described species, and a seventh known but undescribed one, we are now about to get a clearer picture of the most significant species diagnostic characters in Meristoderes. The key characters to distinguish species of the genus appear to be closely connected to cuticular structures on segments 2 and 8 -in fact, all species known so far can be distinguished solely by the appearance of spines/tubules/glandular openings on these two segments, and three species solely by segment 8. Meristoderes galatheae is the only species without a middorsal spine on this segment. At the same time, $M$. galatheae is the only species with only a single, short middorsal spine on segment 4 . The six other species have fairly long middorsal spines on segments 4,6 and 8.

Two different unique versions of segment 8 are found in Meristoderes sp. and in M. imugi sp. nov. In the first, tubules are present in laterodorsal positions, whereas M. imugi sp. nov. has tubules in sublateral positions. Four other species have tubules in lateral accessory positions on this segment, but the displacement of the tubules to sublateral positions in M. imugi sp. nov. is so distinct that it cannot be confused with the condition in other species (compare e.g. Figs. 7f, 8e with Figs. 4i, 5c).

The four remaining species can, based on the appearance of their segment 8 , be grouped two and two together. Meristoderes elleae nov. sp. and M. glaber nov. sp. both lack tubules on segment 8 . Instead, they both show a set of glandular cell outlets type 2 in the lateral accessory positions. Switching focus to segment 2, the two species are easily distinguished though, as only $M$. glaber sp. nov. possesses subdorsal tubules. This species is furthermore easily distinguished by the lack of well-developed cuticular hairs, the missing lateroventral spines on segment 7 , and the displacement of spines to the lateral accessory position on segment 7. Meristoderes elleae sp. nov., on the other hand, is the only species of the genus with glandular cell outlets type 2 in midlateral positions on segment 6 .

The other species couple, $M$. herranzae sp. nov. and the European species $M$. macracanthus, both have middorsal and lateroventral spines and lateral accessory tubules on segment 8 . The two species differ by segment 2 though, where $M$. herranzae sp. nov. has a pair of laterodorsal tubules.

Below follows two short keys, a dichotomous and a multiple entry key (Table 9), to ease identification of species of Meristoderes.

Dichotomous identification key to species of Meristoderes

1. Middorsal spines present on segments 4,6 and 8

A short middorsal spine present on segment 4 only

2. No tubules present in dorsal series of segment 2

Tubules present in dorsal series (subdorsal or laterodorsal) of segment 2

3. Tubules in lateral accessory positions on segment 8

Glandular cell outlet type 2 present in lateral accessory position on segment 8 , and in laterodorsal and sublateral position on segment 2 , and sublateral position on segment 6

4. Lateroventral spines present on segment 6; tubules present in dorsal or lateral series on segment 8; cuticular hairs on most segments

Lateroventral spines absent on segment 6 , no tubules on segment 8 ; cuticular hairs reduced to tiny scales 5. Segment 8 with lateral accessory tubules 6 Segment 8 with sublateral tubules

6. Segment 8 also with subdorsal tubules Segment 8 without subdorsal tubules
2

M. galatheae

3 4

M. macracanthus

M. elleae sp. nov.

M. glaber sp. nov.

M. imugi sp. nov. Meristoderes sp. M. herranzae sp. nov. 
Table 9 Multiple entry key to species of Meristoderes

\begin{tabular}{|c|c|c|c|c|c|c|c|c|c|}
\hline \multirow[t]{2}{*}{ Species } & \multicolumn{9}{|c|}{ Character } \\
\hline & A & B & $\mathrm{C}$ & $\mathrm{D}$ & $\mathrm{E}$ & $\mathrm{F}$ & G & $\mathrm{H}$ & I \\
\hline M. elleae sp. nov. & 0 & 1 & 0 & 0 & 0 & 0 & 1 & 1 & 2 \\
\hline M. galatheae & 1 & 1 & 0 & 0 & 0 & 2 & 2 & 0 & 0 \\
\hline M. glaber sp. nov. & 0 & 0 & 1 & 1 & 0 & 0 & 0 & 0 & 1 \\
\hline M. herranzae sp. nov. & 0 & 1 & 0 & 2 & 0 & 2 & 0 & 0 & 0 \\
\hline M. imugi sp. nov. & 0 & 1 & 0 & 1 & 0 & 1 & 0 & 0 & 0 \\
\hline M. macracanthus & 0 & 1 & 0 & 0 & 0 & 2 & 0 & 0 & 0 \\
\hline Meristoderes sp. & 0 & 1 & 0 & 2 & 1 & 2 & 0 & 0 & 0 \\
\hline
\end{tabular}

Characters: A Middorsal spines: 0 , on segments 4, 6, 8; 1: on segment 4 only. B lateroventral spines on segment 6: 0 , absent; 1 , present. C Position of spines in lateral series on segment 7: 0, lateroventral; 1, lateral accessory. D Tubules in dorsal series of segment 2: 0, absent; 1, subdorsal; 2, laterodorsal. E Tubules in dorsal series of segment 8: 0 , absent; 1, laterodorsal. F Tubules in lateral series of segment 8: 0 , absent; 1 , sublateral; 2, lateral accessory. G Glandular cell outlets type 2 (gco2) on segment 2: 0, absent; 1, laterodorsal and sublateral; 2, subdorsal and lateroventral. H Gco2 on segment 5: 0, absent; 1, sublateral. I Gco2 on segment 8: 0, absent; 1, sublateral; 2, lateral accessory position

Consistently occurring morphological characters in Meristoderes

When Herranz et al. (2012) described Meristoderes as a new kinorhynch entity, the crown character for the genus was the special composition of segment 2, that with its incomplete tergosternal fissures is partially differentiated into a sternal and a tergal plate. With only two species included in the original description, it was hard to point out other characters that occurred consistently among all species, but with the novel information from the current contribution, we can identify additional traits.

Especially the morphology of segment 1 , and to some extent segment 2, seems to be fairly constant across the genus. All seven species have a middorsal pore field (gco1) on segment 1 , and sensory spots in subdorsal and laterodorsal positions (Herranz et al. (2012) reports midlateral instead of laterodorsal sensory spots in M. galatheae, but the sensory spots are so close to the laterodorsal positions that it becomes a bit subjective whether they should be referred to as laterodorsal or midlateral). Also some structures on segment 2 seem to be present consistently in all species. These include middorsal and ventromedial sensory spots, and tubules in ventrolateral positions. However, it should be noted that segment 2 also shows great variation, regarding presence or absence of tubules in the dorsal series. Other consistently occurring sensory spots include a pair in ventromedial position on segment 6 and in paradorsal position on segment 9 .

Spines in the dorsal series most often occur in middorsal positions on segments 4, 6 and 8. Meristoderes galatheae represents the single known exception, with only a tiny middorsal spine on segment 4 . It is noteworthy that no species show middorsal spines on all segments from 4 to 8 , even though this is by far the most common spine pattern in species of Echinoderes (see, e.g., Adrianov et al. (2002) for the most recent key to species of Echinoderes), as well as species of the less diverse genera Cephalorhyncha (see Adrianov and Malakhov 1999; Sørensen 2008a) and Fissuroderes (see Neuhaus and Blasche 2006), and the monotypic Polacanthoderes Sørensen 2008. In the lateral series, tubules are present in lateroventral position on segment 5 , and spines in same positions on segments 8 and 9. Regarding lateroventral spines on segments 6 and 7, one species, M. glaber sp. nov., differs from the others by having no spine on segment 6 and the spine displaced to a lateral accessory position on segment 7 .

Sexual dimorphism is displayed in the presence of lateral terminal accessory spines in females only-a very common sexual character in species of Echinoderidae (e.g. Sørensen and Pardos 2008). But also two other characters attract special attention regarding sexual dimorphism. One regarding the morphology of the male penile spines, and the other regarding the appearance of the laterodorsal tubules on segment 10. When Herranz et al. (2012) described M. macracanthus, they noticed that the laterodorsal tubules on segment 10 in females were reduced to short, hook-shaped appendages, whereas males showed regular long tubules-a condition that otherwise was known only from one species of Echinoderes, E. rex (see Lundbye et al. 2011). A reduction, or at least modification, of the female tubule on segment 10 also occurs in all the new species of the present contribution, hence, what seems to be the exception in Echinoderes seems to be the rule in Meristoderes. The other interesting sexually dimorphic trait regards the penile spines. Whereas most other males in species of Echinoderidae have two, or usually, three tubular penile spines, the median penile spine in all the newly described species is modified into a large, triangular structure with fringed or wrinkled tip. The median penile 
spine in $M$. macracanthus has exactly the same appearance (M. V. Sørensen personal observations, but see also Fig. $6 f$ in Herranz et al. 2012), whereas the detailed penile spine morphology in M. galatheae is uncertain because the only male available for SEM is mounted on segment 11 and examination of the spines is difficult. Enlarged median penile spines have also been reported from species of Echinoderes, for example, E. kanni Thormar and Sørensen 2010, and the character cannot be autapomorphic for Meristoderes, but at least it appears with a consistency which suggests that the large, triangular median penile spine is a ground pattern character for the genus. Interestingly, species of Cephalorhyncha - the genus that shows greatest resemblance to Meristoderes regarding segment 2 morphology-do not have the enlarged median penile spines (M. V. Sørensen personal observations, but see also Fig. 11f in Sørensen 2008a). This indicates that the character also has taxonomic significance and helps to discriminate between species of the two genera.

The last character to mention here regards the overall appearance of some members of the genus. When working with specimens of Meristoderes, one gets the impression that they are unusually fragile, with a rather thin cuticle that easily collapses and cuticular joins (intersegmental as well as those between the tergal and sternal plates) that easily break. The risk of damaging specimens during preparation for LM is much higher than usual, compared to species of other closely related species. Also when examined with SEM, some species appear to have a very thin cuticle that take shape after the underlying pachycycli. This thin cuticle is most conspicuous in M. herranzae sp. nov., $M$. imugi sp. nov. and M. macracanthus, and least in Meristoderes sp. A character like this cannot really be defined in any exact way, and it is in many ways strongly subjective, but still, with a little experience with echinoderid morphology, it becomes quite distinct and is therefore relevant for morphological comparisons.

Hence, several characters appear to be shared by all or most species of Meristoderes, but at the same time, the finding of the five new species puts a questionmark to the original crown character for the genus, namely the partially developed tergosternal fissures on segment 2 (see Herranz et al. 2012). When additional species are discovered and assigned to newly erected genus with only one or a few known species, it is not uncommon that some characters, inclusive some diagnostic and significant ones, turn out to be more disparate or variable than previously thought. The present study reveals, not very surprisingly, that this partial tergosternal fissure on segment 2 may vary in distinctness and completeness. In the two first species of the genus, M. macracanthus and M. galatheae, the fissures were only present on the posterior third of segment 2, but in some of the new species described in the present study, they extent more anterior. This culminates in $M$. glaber sp. nov. that apparently has complete fissures all through segment 2 . The varying degree of completeness in the tergosternal fissures of the new species does not really challenge their assignment to Meristoderes. However, M. glaber sp. nov. is slightly problematic, because it basically does not comply with the original genus diagnosis of Meristoderes that clearly states that the tergosternal divisions should be partial only (Herranz et al. 2012). The only alternative genus assignment of the species would be Cephalorhyncha though, but the species does not fit in here either since the genus' diagnosis restricts it to accommodate species with " 2 nd trunk segment composed of arched tergite and sternal plate incompletely subdivided by midventral articulation into 2 substernites" (Adrianov and Malakhov 1999). Even though M. glaber sp. nov. obviously does not fit into any of the new genera, it still complies best with Meristoderes, also regarding some of the additional minor characteristics mentioned above. The conditions of segment 2 in Meristoderes and Cephalorhyncha are assumed to represent intermediate stages between the condition in Echinoderes, with the segment forming a completely closed ring, and in Polacanthoderes and Fissuroderes where segment 2 is composed of one tergal and sternal plates (see discussion by Herranz et al. 2012). Keeping this transition from well-defined tergal plates towards a closed ring (or eventually the opposite) in mind, it must be expected that the tergosternal divisions may be partial in some species and more complete in others. M. glaber n. sp. is one of those with complete divisions.

A third alternative would be to erect a new genus to accommodate this single species, but this solution is not very desirable. The phylogeny and classification of Echinoderidae still contains several unresolved questions (see Sørensen 2008b). Furthermore, the family already accommodates two genera that are defined by intermediate conditions between two other genera, which make them both potentially paraphyletic. Adding a third new genus to this group could lead to additional future problems, rather than provide clarification. Hence, among the solutions considered here, we prefer tentatively to assign $M$. glaber sp. nov. to Meristoderes, but we would like to stress that the phylogenetic pathways in Echinoderidae are far from being solved, and we encourage future phylogenetic studies to focus on these two intriguing genera and to test their monophyly.

Comparison of morphological characters in Meristoderes and other Echinoderidae

Information on the arrangement of scalids on the introvert is already available from M. macracanthus (see Herranz et al. 2012) and is now supplemented with observations from $M$. herranzae sp. nov. The scalid arrangement in the two species is identical in the anteriormost rings, whereas 
they differ in the more posterior ones. Some trends are quite clear though: First, both species tend to have the highest number of scalids in uneven numbered sections, and secondly, most differences in the posteriormost rings appear to be due to a reduction/loss of scalids in $M$. herranzae sp. nov. Having more scalids in uneven numbered sections is a common trend, and it seems to be the condition in a majority of species among cyclorhagids as well as homalorhagids (see e.g. Sørensen et al. 2010a, 2012a, b). Exceptions are Polacanthoderes martinezi, Zelinkaderes klepali, and Z. brightae that have more scalids in even numbered sections (see Bauer-Nebelsick 1995; Sørensen et al. 2007; Sørensen 2008), and Condyloderes megastigma, Triodontoderes anulap and Z. floridensis that have the same number of scalids in all sections (see Higgins 1990; Sørensen and Rho 2009; Sørensen et al. 2010c).

Also the differences of scalid numbers in the posterior introvert rings have been reported previously. It appears that the trichoscalid plates in some instances take up the space so that scalids which otherwise would occupy the position are lost. This seems to be the case in introvert sections 2, 4, 8, and 10 of $M$. herranzae sp. nov., that all lack a lateral scalid in Ring 05. Correspondingly, one scalid in Ring 05 and one in Ring 07 have been reduced due to trichoscalid plate occupancy in M. macracanthus (see Herranz et al. 2012), but it seems that this scalid reduction has been taken even further in M. herranzae sp. nov. Other examples of asymmetrical introvert sections due to loss of scalids near trichoscalid plates have been reported from Echinoderes applicitus, E. cernunnos, E. microaperturus and other recently described species of Echinoderes (Ostmann et al. 2012; Sørensen et al. 2012b).

Even with some scalids lost, $M$. herranzae sp. nov. still have more scalids in its posterior rings than most other non-echinoderid genera. This appears to be a general echinoderid trend that recently were addressed in a comparison of scalid patterns in species of Dracoderes and other kinorhynch genera (Sørensen et al. 2012a). The scalid arrangement in $M$. herranzae sp. nov. is unique, but it shows the greatest resemblance to M. macracanthus and species of Echinoderes (see, e.g., Herranz et al. 2012; Ostmann et al. 2012; Sørensen et al. 2012b).

Besides differences in scalid positions and occasional scalid losses, another echinoderid specialty is the morphology of the scalids that also tends to vary more in the posterior rings. For instance, the so-called leaf-like scalids (i.e. scalids with broad bases and fringed lateral edges) were recently described from the posteriormost scalid rings in some species of Echinoderes (Sørensen et al., 2012b). Similar scalids also seem to occur in the posteriormost rings of $M$. macracanthus. The authors do not use the term "leaf-like", but describe scalids in Ring 07 as having "...a wide and hairy base from where several flexible elongations arise" (see page
7 in Herranz et al. 2012). In the present contribution, we can report the presence of another kind of appendages, namely small cuticular tufts that are interpret as rudimentary scalids (Fig. 4b). This great disparity in scalid and introvert morphology makes a comparison across the echinoderid species less straight forward, but the variation also indicates that the introvert may provide characters that can resolve relationships between closely related species. It may furthermore, with much more data made available, be able to provide quite detailed information about echinoderid character evolution. For instance, introvert section 1 in M. herranzae sp. nov. and E. applicitus Ostmann et al. 2012 is identical in all but the seventh and most posterior ring. Here, E. applicitus has three scalids, whereas $M$. herranzae sp. nov. has a single one only. However, this single scalid is flanked by two of these tufts that are interpreted as rudimentary scalids. If the interpretation is correct, and the rudiments represent either less developed or reduced scalids, introvert section 1 in the two species would have the same scalid patterns but with scalids in slightly different conditions.

Another interesting trend in morphological character evolution for species of Meristoderes regards the composition of segment 11 . Whereas $M$. herranzae sp. nov. and Meristoderes sp. possess a segment with the most common composition, namely one tergal and two sternal plates, M. imugi sp. nov., M. elleae sp. nov., and M. glaber sp. nov. have the dorsal side of segment 11 formed by two tergal plates with a midtergal joint. Re-examination of M. macracanthus and M. galatheae confirms that their segment 11 has only one tergal plate, as stated in the original description (Herranz et al. 2012).

This condition of segment 11, inclusive its variability at the generic level, is actually not unknown among genera of Echinoderidae. When Neuhaus and Blasche (2006) described Fissuroderes, they showed that three out of the five new species that were assigned to the genus had a terminal segment with two tergal plates. They furthermore re-assigned E. nybakkeni (Higgins 1986) to Cephalorhyncha, and showed that also C. nybakkeni and C. asiatica (Adrianov 1989) had a divided tergal plate on segment 11. Among species of Echinoderes, the composition of segment 11 has appeared to be more fixed and apparently always composed of a single tergal and two sternal plates only, but recently a species, E. cernunnos Sørensen et al., 2012b, with middorsally divided tergal plate on segment 11 was actually described. Hence, the tergal plate of segment 11 seems to show morphological plasticity in all echinoderid genera (except in the monotypic Polacanthoderes). The phylogenetic significance of the condition of this tergal plate would of course have to be tested in a numeric cladistic analysis, but the taxonomically widespread occurrence of divided tergal plate on segment 11 suggests that the condition probably evolved more than once. 


\section{Conclusions}

Our survey of kinorhynchs in Korean waters and nearby localities resulted in the discovery of no less than five new species of Meristoderes, of which four are formally described. This brings the total number of described species up to six, of which one is European and the remaining five are from East Asia. This distribution suggests that the genus contains much more unrecovered biodiversity, and that species of the genus can be expected at marine localities throughout the Old World.

Taxonomically the species are rather unproblematic, and species identification is primarily based on classic characters such as spine/tubule positions, and a "neo-classic" one, namely occurrence of the conspicuous glandular cell outlets type 2. Potential taxonomic problems are more relevant at the generic level. Even though the genus diagnosis appears pretty straight forward regarding the presence of tergosternal fissures on segment 2, the developmental level of these fissures varies greatly among species, and one could speculate if there are species that phylogenetically belong to the genus, but have tergosternal fissures so indistinct that they cannot be visualized with conventional SEM/LM. Such species would erroneously be assigned to Echinoderes and hence result in an incorrect taxonomy. One way to overcome this would be to identify additional diagnostic characters for the genus. No unambiguous new characters have been revealed in the present study, but one should keep the problem in mind in future studies.

Acknowledgments We send our warm thanks to Stine Elle for preparing the line art illustrations, and to Dr. B. J. Lim and Dr. J. Y. Park for their assistance in collecting samples. This work was supported by the project "Discovery of Indigenous Species from Korea" sponsored by the National Institute of Biological Resources (NIBR), Korea. Support was furthermore obtained through the research program of KORDI with contract numbers PM56900 and PE98753 to HSR, and through the Danish Natural Science Research Council (Grant No. 09-066003) to MVS.

\section{References}

Adrianov AV (1989) The first report of Kinorhyncha of the Sea of Japan. Zool Zh 68:17-27

Adrianov AV, Malakhov VV (1999) Cephalorhyncha of the world ocean. KMK Scientific Press, Moscow

Adrianov AV, Murakami C, Shirayama Y (2002) Echinoderes aureus n. sp. (Kinorhyncha: Cyclorhagida) from Tanabe Bay (Honshu) - first representative of the genus in the Pacific Ocean. Proc Biol Soc Wash 115:205-216

Bauer-Nebelsick M (1995) Zelinkaderes klepali sp.n., from shallow water sands of the Red Sea. Ann Nat Mus Wien 97B:57-74

Bütschli O (1876) Untersuchungen über freilebende Nematoden und Gattung Chaetonotus. Z wiss Zool 23:363-413

Herranz M, Thormar J, Benito J, Sánchez N, Pardos F (2012) Meristoderes gen. nov., a new kinorhynch genus, with the description of two new species and their implications for echinoderid phylogeny (Kinorhyncha: Cyclorhagida, Echinoderidae). Zool Anz 251:161-179

Higgins RP (1986) A new species of Echinoderes (Kinorhyncha: Cyclorhagida) from a coarse-sand California beach. Trans Am Microsc Soc 105:266-273

Higgins RP (1990) Zelinkaderidae, a new family of cyclorhagid Kinorhyncha. Smithson Contrib Zool 500:1-26

Higgins RP, Kristensen RM (1988) Kinorhyncha from Disko Island, West Greenland. Smithson Contr Zool 458:1-56

Lundbye H, Rho HS, Sørensen MV (2011) Echinoderes rex n. sp. (Kinorhyncha: Cyclorhagida)—the largest Echinoderes species found so far. Sci Mar 75:41-51

Neuhaus B, Blasche T (2006) Fissuroderes, a new genus of Kinorhyncha (Cyclorhagida) from the deep sea and continental shelf of New Zealand and from the continental shelf of Costa Rica. Zool Anz 245:19-52

Ostmann A, Nordhaus I, Sørensen MV (2012) First recording of kinorhynchs from Java, with the description of a new brackish water species from a mangrove-fringed lagoon. Mar Biodiv 42:79-91. doi:10.1007/s12526-011-0094-z

Sørensen MV (2008a) A new kinorhynch genus from the Antarctic deep sea and a new species of Cephalorhyncha from Hawaii (Kinorhyncha: Cyclorhagida: Echinoderidae). Org Div Res 8:230.e1-230.e18. doi:10.1016/j.ode.2007.11.003

Sørensen MV (2008b) Phylogenetic analysis of the Echinoderidae (Kinorhyncha: Cyclorhagida). Org Div Evol 8:233-246

Sørensen MV, Pardos F (2008) Kinorhynch systematics and biology-an introduction to the study of kinorhynchs, inclusive identification keys to the genera. Meiofauna Mar 16:21-73

Sørensen MV, Rho HS (2009) Triodontoderes anulap gen. et sp. nov.-a new cyclorhagid kinorhynch genus and species from Micronesia. JMBA 89:1269-1279

Sørensen MV, Heiner I, Ziemer O, Neuhaus B (2007) Tubulideres seminoli gen. et $\mathrm{sp}$. nov. and Zelinkaderes brightae sp. nov. (Kinorhyncha, Cyclorhagida) from Florida. Helgoland Mar Res 61:247-265

Sørensen MV, Pardos F, Herranz M, Rho HS (2010a) New data on the genus Paracentrophyes (Homalorhagida, Kinorhyncha), with the description of a new species from the West Pacific. Open Zool J 3:42-59

Sørensen MV, Rho HS, Kim D (2010b) A new species of the rare genus Sphenoderes (Cyclorhagida, Kinorhyncha), with differential notes on S. indicus Higgins, 1969. Mar Biol Res 6:472-484

Sørensen MV, Rho HS, Kim D (2010c) A new species of Condyloderes (Cyclorhagida, Kinorhyncha) from Korea. Zool Sci 27:234-242

Sørensen MV, Herranz M, Rho HS, Min W, Yamasaki H, Sanchez N, Pardos F (2012a) On the genus Dracoderes Higgins \& Shirayama, 1990 (Kinorhyncha: Cyclorhagida) with a redescription of its type species, D. abei, and a description of a new species from Spain. Mar Biol Res 8:210-232

Sørensen MV, Rho HS, Min W, Kim D, Chang CY (2012b) An exploration of Echinoderes (Kinorhyncha: Cyclorhagida) in Korean and neighboring waters, with the description of four new species and a redescription of E. tchefouensis Lou, 1934. Zootaxa 3368:161-196

Sørensen MV, Rho HS, Min W, Kim D (2011) A new recording of the rare priapulid Meiopriapulus fijiensis, with comparative notes on juvenile and adult morphology. Zool Anz. doi:10.1016/j.jcz. 2011.10.001

Thormar J, Sørensen MV (2010) Two new species of Echinoderes (Kinorhyncha: Cyclorhagida) from the Solomon Islands. Meiofauna Mar 18:67-96

Zelinka K (1896) Demonstration von Tafeln der EchinoderesMonographie. Verh Deut Z Gesell 6:197-199 